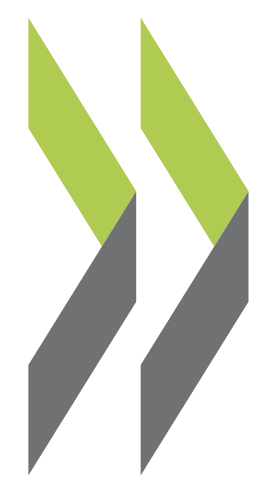

OECD Working Papers on International Investment 2017/04

Have currency-based capital flow management measures curbed international banking flows?
Annamaria de Crescenzio, Marta Golin, Francesco Molteni 


\section{OECD WORKING PAPERS ON INTERNATIONAL INVESTMENT}

OECD Working Papers should not be reported as representing the official views of the OECD or of its member countries. The opinions expressed and arguments employed are those of the authors.

Working Papers describe preliminary results or research in progress by the author(s) and are published to stimulate discussion on a broad range of issues on which the OECD works. Comments on Working Papers are welcomed, and may be sent to investment@oecd.org or the Investment Division Directorate for Financial and Enterprise Affairs, OECD, 2 rue André-Pascal, 75775 Paris Cedex 16, France.

The international investment working paper series - including policies and trends and the broader implications of multinational enterprise - is designed to make available to a wide readership selected studies undertaken under the aegis of the OECD Investment Committee, by OECD staff, or by outside consultants working on OECD Investment Committee projects.

The papers are generally available only in their original language English or French with a summary in the other if available.

OECD WORKING PAPERS ON INTERNATIONAL INVESTMENT are published on www.oecd.org/investment/working-papers.htm.

This document and any map included herein are without prejudice to the status of or sovereignty over any territory, to the delimitation of international frontiers and boundaries and to the name of any territory, city or area.

You can copy, download or print OECD content for your own use, and you can include excerpts from OECD publications, databases and multimedia products in your own documents, presentations, blogs, websites and teaching materials, provided that suitable acknowledgment of OECD as source and copyright owner is given. All requests for commercial use and translation rights should be submitted to rights@oecd.org. 


\title{
Have Currency-Based Capital Flow Management Measures Curbed International Banking Flows?
}

\author{
By \\ Annamaria De Crescenzio, Marta Golin, Francesco Molteni*
}

This paper analyses the impact of a specific type of banking regulation on operations in
foreign currency, defined as currency-based capital flow management measures (CB-CFMs),
on cross-border banking flows in a sample of 18 countries over the period 2005 to 2013 . The
results show that the introduction and tightening of these measures in the post-crisis period
contributed to a reduction of the external debt of banks, controlling for capital flow
management measures, domestic macro-prudential regulation, and a large set of push and
pull factors. The examination of external debt by maturity and instruments suggests that
these measures are more effective in curbing short-term debt and interbank borrowing,
which are also the components that contracted more sharply in the aftermath of the 2008
crisis. Further analysis could look at the benefits these measures bring in terms of financial
stability, and evaluate the costs of capital account openness against the risks that CB-CFMs
aim to address.

Authorised for release by Pierre Poret, Director, OECD Directorate for Financial and Enterprise Affairs.

JEL Classification: E58, F3, F38, G28

Keywords: currency-based measures, capital flow management measures, macro-prudential policies, external debt, banking debt.

\footnotetext{
* Annamaria De Crescenzio is an Economist and Policy Analyst in the OECD Directorate for Financial and Enterprise Affairs, Marta Golin is a Research Fellow at the University of Oxford and Francesco Molteni is a Research Fellow at the European University Institute. The authors would like to thank Pierre Poret, Angel Palerm, Ana Novik, Winfrid Blaschke, Lukasz Rawdanowicz, Kiril Kossev and Etienne Lepers for their contributions. The paper also benefited from comments by the delegates of the Advisory Task Force on the OECD Codes of Liberalisation. Any remaining errors are the authors' alone.
} 


\section{INTRODUCTION}

The debate about the impact of Capital Flow Management measures (CFMs) and MacroPrudential Measures (MPMs) has been very active in recent years. An area that has been discussed actively at the OECD, in particular within the Advisory Task Force on the OECD Codes of Liberalisation and the Investment Committee, has been the use of currency-based measures (CBMs) directed at banks.

In this context, the OECD has collected new datasets of de jure CBMs directed at banks, with CBMs defined as bank regulations discriminating on the basis of the currency of an operation - in other words, measures that apply a less favourable treatment to operations by banks in a particular currency, typically foreign currencies ${ }^{1}$ (De Crescenzio et al., 2015). ${ }^{2}$ The implementation of these currency-based measures has often been justified by the intention to limit the build-up of currency mismatches in the banking sector and the excessive accumulation of bank liabilities in foreign exchange (FX), potentially more volatile than those denominated in domestic currency and could generate external vulnerabilities following the tightening cycle of monetary policy in Advanced Economies (AEs) (see OECD, 2015). ${ }^{3}$

The vast majority of CBMs aim to address financial stability concerns. However, some CBMs which are also CFMs may also affect capital mobility, among other things. Therefore, when considering the implementation of these regulations, policy makers need to keep into account the issue of proportionality of CBMs to the risks they are trying to address, assess whether these measures do not create unnecessary impediments to capital mobility, and be satisfied that they do not substitute for less restrictive alternative solutions.

This paper contributes to the dialogue on these financial regulations by assessing the impact of a specific subset of CBMs on cross-border banking flows, using a comprehensive dataset that covers 18 countries over the period 2005-2013. The dataset includes push and pull determinants of international capital flows, banking characteristics and other regulatory policies, such as domestic MPMs as well as traditional capital controls that do not discriminate on the basis of the currency of an operation but rather by the residency of the counterparty.

\footnotetext{
${ }^{1}$ CBMs encompass a broad category of measures: regulations imposing a different treatment between domesticcurrency and FX-denominated operations by banks. CBMs may target operations among residents, or operations also with non-residents. Within this latter broad category, CMBs may have the character of CFMs, as they extend to operations abroad with non-residents. Among Currency-Based CFMs, those measures that apply to operations with non-residents only are traditionally defined as capital controls.

2 The analysis of the datasets showed that the use of these measures increased in the aftermath of the recent financial crisis, with the implementation of tightening actions being particularly intense in the years 2010 and 2011 , especially by Emerging Market Economies (EMEs) - a similar trend as that observed for traditional capital controls (see Fernandez et al. 2015).

${ }^{3}$ It is also of interest that tightening actions on CB-CFMs targeting bank liabilities have mainly been implemented by countries suffering from the so-called "original sin", i.e. those countries that face severe limitations to borrowing in their domestic currency in international markets.
} 
In particular, the analysis focuses on those CBMs that not only discriminate on the basis of the currency of an operation but also extend to operations abroad with non-residents and that thus may be considered CFMs - defined as CB-CFMs. The original dataset (De Crescenzio et al., 2015) excludes those measures that are considered as common domestic prudential tools, as well as those that apply to operations with residents only.

The main findings in the paper can be summarised as follows:

- $\quad$ CB-CFMs are found to reduce short-term cross-border banking flows, measured as banks' debt in the hands of non-residents, one quarter after their implementation; this result is in line with the stated intent of the majority of CB-CFMs aimed at reducing capital flow volatility arising from short-term flows.

- Some domestic macro-prudential regulations (limits on Loan To Value (LTV), Debt To Income (DTI), Dynamic Provisioning (DPs)) may contribute to the reduction in the external debt of banks one quarter after their implementation, but these results are not confirmed in robustness checks. ${ }^{4}$

- Looking at the breakdown of banks' external debt by instrument, empirical findings suggest that CB-CFMs are more effective in reducing loans than securities or deposits. As a result, they also affect the composition of international banking flows, they can have an impact on the interest rates of different debt instruments, and may introduce price distortions in the domestic debt market.

The results presented in this study are subject to a number of limitations. First, the analysis exploits macro-data for the banking sector, whilst it would be useful to study the impact of CB-CFMs with micro-level data to capture the effect of CB-CFMs given different bank characteristics. Further research should also aim at finding better indicators to capture the policy stance of CB-CFMs: whilst the index captures the directionality and frequency of changes in the use of CB-CFMs, it does not allow scoring the intensity of a single action. Indeed, in practice some "tightening" actions may be more restrictive than others and some "easing" actions may be more liberalising than others. This drawback is shared by a large number of empirical studies that aim to assess the impact of CFMs or MPMs on different economic variables, as the literature has so far not made progress on the scoring of the intensity of measures. In addition, notwithstanding the importance of assessing the impact of CB-CFMs on cross-border banking flows and on different debt instruments, further research should aim to measure the effect of these measures on total capital flows.

Examining the composition of global capital inflows and outflows by assets, namely banking flows, portfolio flows and FDI flows, it is evident that all types of capital flows declined during the crisis, but the decline in banking flows was especially sharp. Indeed, international banking flows reversed after 2008, indicating that banks not only stopped lending money abroad, but also liquidated foreign exposures; in 2013 banking flows had not recovered to their pre-crisis level yet. According to various scholars this retrenchment of banks might be an important factor driving the recent trend in financial deglobalisation. Given the large importance of banking flows relative to overall capital flows, for the purpose of the study if CB-CFMs are found to negatively affect banking flows, it is possible that these banking regulations might have affected total capital flows as well. Further consideration should also be given to how the impact on CB-CFMs changes in countries with different sizes of the banking system relative to overall capital flows.

\footnotetext{
${ }^{4}$ Results are, however, not robust to the robustness check where we exploit the difference GMM estimator.
} 
Multilateral cooperation should also aim at monitoring the use of CB-CFMs and their effects on a larger set of economies and at measuring possible spillovers of CB-CFMs across countries and sectors. In particular, further analyses could be carried out on the effects of regulation on bond issuance in the nonfinancial sector, which has steadily increased in the aftermath of the 2008 crisis.

Finally, this study specifically looks at the impact of CB-CFMs on international banking flows without considering other potentially positive effects that these measures may have on financial stability. It would be useful to complement this analysis with information on the effectiveness of CB-CFMs in addressing financial stability concerns, so that a more informed assessment could be made on whether these measures come with costs that are proportionate to the benefits they bring and the risks they aim to address.

The rest of the paper is organised as follows: Section I shows the importance of banking flows and compares this study with other recent works that assess the impact of MPMs and CFMs on international capital flows; Section II describes the data used in the empirical analysis and trends related to banking flows and the use of CB-CFMs in the pre- and post-crisis period; Section III presents the econometric methodology and summarises the results of the empirical analysis; and Section IV concludes. 


\section{THE BOOM-BUST DYNAMICS OF BANKING FLOWS AND THE ROLE OF CURRENCY- BASED CAPITAL FLOW MANAGEMENT MEASURES}

\section{Global liquidity, the pro-cyclicality of banking flows and the "Great Retrenchment"}

The expression "global liquidity" is commonly used in the context of the geography of capital flows in global financial markets, referring to the factors that drive the supply of funding from international financial centres and affect the ease of global financing. Interconnected financial intermediaries transmit global liquidity through cross-border claims in a long and complex intermediation chain until the ultimate local borrower. The international banking system has therefore become an important conduit for the transfer of capital across countries, allowing for the reallocation of savings towards countries with more productive investment opportunities.

However, as witnessed during the recent crisis and highlighted in the literature on sudden stops (see Calvo, 1998; Calvo and Reinhart, 2000; Calvo and Talvi, 2005), banking flows have shown strong pro-cyclicality and can abruptly reverse. ${ }^{5}$ Furthermore, to the extent that banking inflows are largely denominated in FX (Figure 1), while the activity of financial intermediaries is mainly denominated in domestic currency and is not completely hedged against currency risk, capital inflows might expose the banking system to currency mismatches, which undermine financial stability in case of sharp depreciation of the exchange rate. This mechanism, which was at the root of the twin crisis in the 1990s - the simultaneous combination of currency and banking crises (Kaminsky and Reinhart, 1999; Ahrend et al., 2012) - could return to the centre of the policy debate in consideration of a monetary tightening phase in AEs. Therefore, understanding the determinants of global liquidity and of cross-border banking flows is a central issue for both international financial integration and financial stability purposes.

Figure 1 compares the evolution of international bond flows (solid line) with cross-border banking flows (broken line), each as a share of global GDP. These two types of debt flows strongly comoved until 2008 and then decoupled: in the wake of the global financial crisis bond flows steadily increased, almost converging to the level of banking flows, which instead sharply declined (see also Avdjiev et al., 2014; Shin, 2013; Feyen et al., 2015; FSB, 2015).

Structural and cyclical factors can explain the boom-bust pattern in banking flows. Deeper financial integration and the removal of restrictions on international capital mobility (Milesi-Ferretti and Tille, 2011) can partly account for the up-ward trend of banking flows in the run-up to the crisis, with banking flows increasing from $30 \%$ of global GDP in 2000 to $50 \%$ in 2008. In addition, loose monetary policy in the centre of the international financial system, by easing the financing conditions of global banks, increased their risk-taking, which resulted in a boost of their leverage and of cross-border banking claims (Adrian and Shin, 2013; Bruno and Shin, 2015; Rey, 2015; Forbes and Warnock, 2012).

The retrenchment of banking flows in the aftermath of the recent global crisis has been more pronounced than that of other types of capital flows, with banks significantly limiting their FX borrowing

\footnotetext{
${ }^{5}$ Catão and Gian Milesi-Ferretti (2014) find that banking flows, more than other capital flows, have a strong predictive power for the occurrence of financial crises.
} 
operations to minimise FX liabilities; this is especially true for European banks, which cut back crossborder lending (IMF, 2015). Banking flows have not resumed their pre-crisis level despite the abundant liquidity provision of central banks, which led to an ease of both the funding conditions of banks in the financial centres and financial stress and brought risk appetite to resurge. ${ }^{6}$

Figure 1. Breakdown of banking and bond flows (2000-2013)

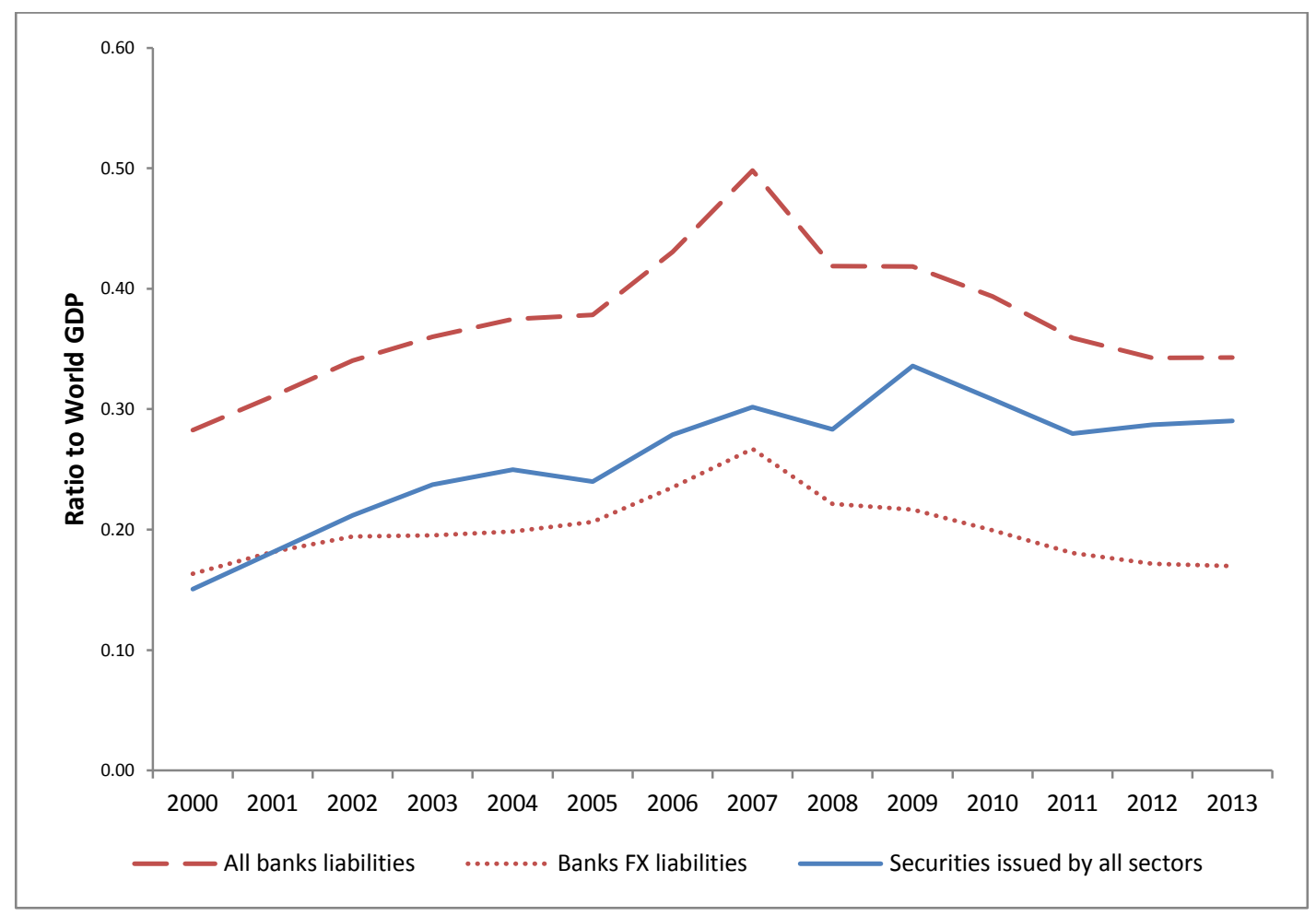

Source: OECD staff calculation from BIS Locational Banking Statistics Tables 6A-6B and 11A-11B and World Bank data.

The effort of banks in the centre of the financial system to deleverage in the aftermath of the crisis is a primary cause of the decline in cross-border banking flows. Nevertheless, given unprecedented accommodative monetary policies, other factors could explain the retrenchment of cross-border banking flows; in particular new banking regulations on international operations or operations in foreign currency, such as CB-CFMs, which were introduced to enhance the resilience of the financial system, may have also restricted capital flows channelled via the international banking system (see also IMF 2015).

\section{What is the role of CB-CFMs in reducing cross-border banking flows?}

This paper evaluates the impact of changes in regulation of banks' operation in foreign currency on cross-border banking flows. More specifically, it considers a subset of CBMs, those which extend to operations with non-residents and which are therefore part of the broader class of CFMs; this subset of measures is defined as currency-based CFMs (CB-CFMs). Since these banking regulations target operations in FX, they are a natural suspect of regulations affecting international banking flows.

\footnotetext{
${ }^{6}$ Empirical evidence shows that investors' risk aversion, measured by the VIX index, reduces significantly following unconventional monetary policy (Gambacorta et al. 2014) and a loosening of conventional monetary policy (Bekaert et al., 2013) of central banks in AEs.
} 
Using a novel dataset (De Crescenzio et al. 2015), the paper tests the null hypothesis that the introduction or a tightening of CB-CFMs reduces cross-border banking flows, controlling for the effect of domestic MPMs, other CFMs, bank characteristics and a large set of push and pull factors.

The main finding of this paper is that these regulations significantly reduce cross-border banking flows and especially their short-term component. Therefore, these measures may share the drawbacks of other standard CFMs of raising issues regarding international commitments to cross-border openness. Banking flows have increased considerably during 2000s for all income groups, thus becoming the largest share of flows before the crisis, especially in AEs (Broner et al., 2013; Milesi-Ferretti and Tille, 2011; Bussière et al., 2016). ${ }^{7}$ Consequently, CB-CFMs targeting banks, if contributing to the reduction of banking flows, could also significantly affect aggregate capital flows and introduce an impediment to international capital mobility and ultimately real investment.

\section{The impact of CFMs on capital flows}

The paper is closely connected to recent studies that examine the impact of MPMs and CFMs on capital flows and in particular on cross-border banking flows. Bruno et al. (2015) assess the impact of both MPMs and CFMs on banking and bond inflows in 12 Asia-Pacific economies over 2005-2013. They conclude that bank and bond inflow CFMs do affect inflows and sectoral-type policies affect the composition of capital flows: after 2009 they find that controls on bond flows stimulate bank capital flows, and prior to 2007, controls on bank flows affected bond flows. The aim of this paper and econometric approach is closely related to this work but it considers a different set of regulations (CB-CFMs) and provides a more granular analysis on the impact these policies on different components of cross-border banking flows.

In a panel-regression study carried out on 37 countries, Blundell-Wignall and Roulet (2013) confirm previous empirical research that sees capital controls on inflows as part of a broader set of exchange rate targeting policies; additionally, they find that controls on bond inflows limit the upward pressure on managed exchange rates in good times and allow for export competitiveness to remain high; however, in bad times, when small companies are more dependent on bank financing and this is restricted by capital controls, regulations on inflows may severely limit GDP growth.

While the standpoint of this paper is from the perspective of host countries (borrowers), other studies analyse the impact of banking regulation on home countries (lenders). The IMF Global Financial Stability Report (2015) collects data on regulation of banks' international operations and finds that tighter regulations are associated with a reduction in cross-border lending both in home and host countries, whereas changes in capital requirements affect cross border claims in home countries but not host countries. Using bank-level data from the UK, Forbes et al. (2015) find that increases in micro-prudential capital requirements tend to reduce international bank lending and this effect is amplified by the interaction with unconventional monetary policy. By contrast, Cerutti et al. (2014) find that more stringent capital requirements make cross-border flows less cyclical and reduce the level of cross-border inflows to banks. The results of the study support the empirical findings of IMF (2015) concerning the impact of CB-CFMs on international banking flows.

Other works analyse the impact of CBMs on capital flows and FX lending, although with a different definition of currency-based measures than that used in this paper. Pasricha et al. (2015) collect data on changes in CFMs and "prudential" CBMs - i.e. CBMs that discriminate based on currency and not

\footnotetext{
${ }^{7}$ These studies consider the category of "Other investment" in the Balance of Payment statistics which encompasses mostly banking flows (see Bussière et al. 2016 for a discussion about the items included in this category).
} 
on residency and apply to the domestic financial sector with the aim of limiting foreign currency risks in individual firms' balance sheets - classified into inflow and outflow measures. ${ }^{8}$ They find that these measures have significant spill over effects to neighbouring countries through exchange rate appreciation and capital flows, especially cross-border banking flows. Qureshi e al. (2011) also make a distinction between foreign currency (FX) - related prudential measures and financial-sector specific capital controls and find that both are associated with a lower proportion of FX loans in domestic bank lending. ${ }^{9}$

Finally, this paper is connected with the recent strand of literature that analyses the impact of domestic MPMs on international capital flows. Beirne and Friederich (2014) assess the impact of MPMs on international banking flows. They find that domestic MPMs targeted at excessive credit growth, maturity mismatches and capital requirements are more effective when the country experiences positive real growth, while a high-share of non-resident bank loans in a country reduces the effectiveness of MPMs. In addition, they show that the geographical spill overs are weak but that spillovers across asset classes within countries are strong.

Whilst the effects of MPMs and CFMs alone have been extensively studied in the recent literature, this paper looks at the impact of measures that discriminate on the basis of the currency of an operation, apply to operations abroad and/or with non-residents and are taken with a stated macroprudential intent. In particular, there is merit in furthering the dialogue on whether these measures may have an impact on cross-border banking flows that is disproportionate to the risks they aim at addressing, also in the context of international commitments to capital account openness. This study also analyses the impact of CB-CFMs on different debt components, namely loans, securities and deposits. The results presented here can help to inform a policy dialogue that aims to understand the channels through which these measures may act.

\footnotetext{
${ }^{8}$ As in this paper, they do not include limits on banks' net open positions in foreign currencies as CBMs.

${ }^{9}$ Similar to our dataset Qureshi et al. (2011) consider currency-based measures applied only to the financial sector, while Pasricha et al. (2015) also include those that limit the non-financial sector's ability to trade foreign currency denominated assets.
} 


\section{DATA AND DESCRIPTIVE TRENDS}

\section{Data on external debt and FX liabilities in the banking sector}

In line with the existing literature cross-border banking flows are defined as the debt of the banking sector vis-à-vis non-residents (external debt). Data on the external debt of banks come from the World Bank's Quarterly External Debt Statistics (QEDS) database. Total external debt is the main dependent variable in the empirical analysis. The breakdown between short-term and long-term external debt and between different debt instruments - namely loans, securities and deposits - to test the effects of CB-CFMs on different components of banks' debt to non-residents is also exploited. Data on all the different breakdowns of external debt, both by maturity and by type of operations, come from the World Bank's QEDS database.

Figure 2. Short-term external banking debt as a share of total external debt of banks, selected countries in the sample (2005-2013)

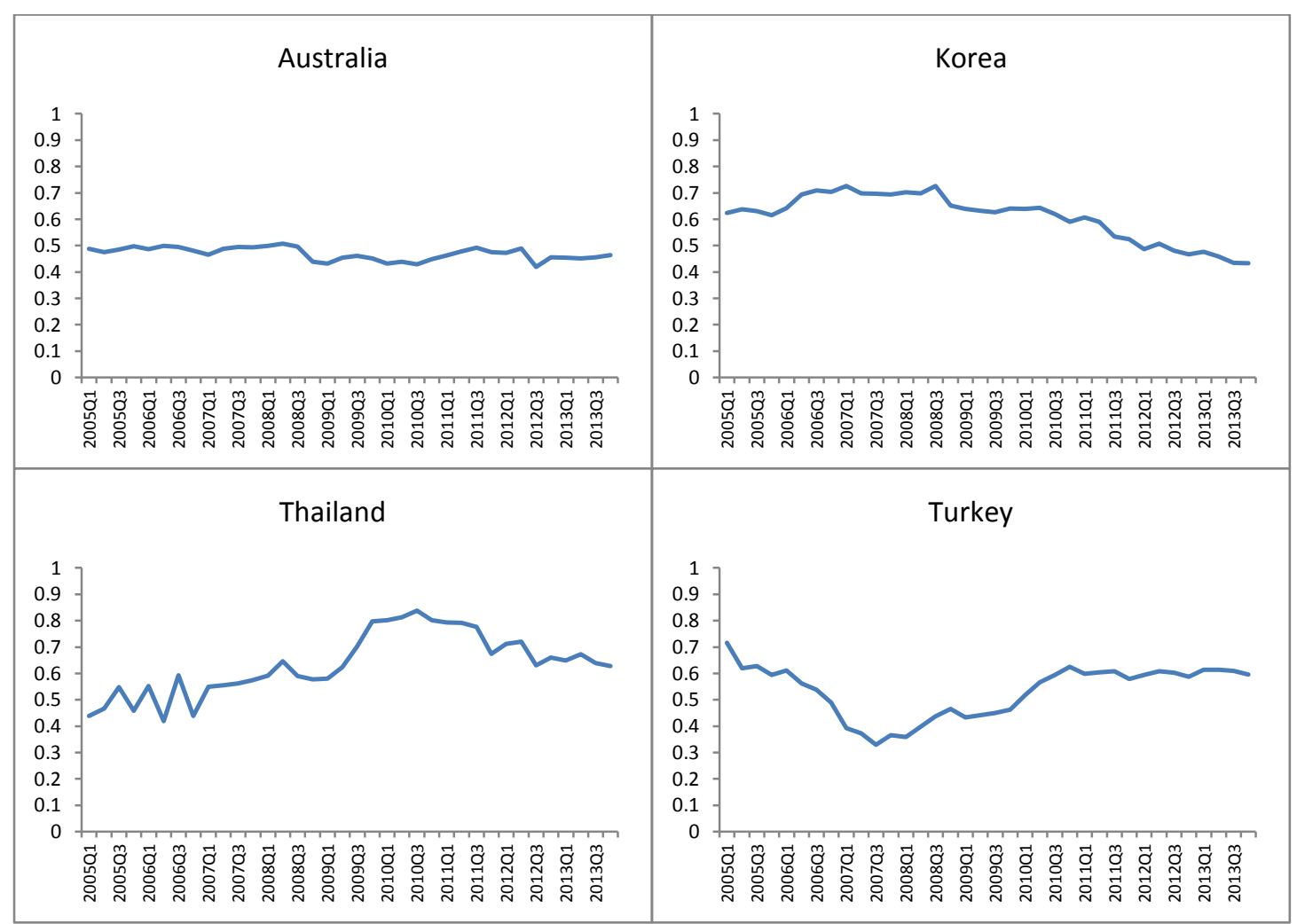

Source: OECD staff calculation using data from World Bank's QEDS database.

Annex 6 contains graphs on the rate of growth of total external debt across countries as well as changes in the share of short-term to total external debt. Figure 2 presents trends in the rate of short-term external debt to total external debt for selected countries. Marked differences can be seen in the evolution of short-term external banking debt in both OECD and non-OECD economies. In particular, large AEs 
often display a lower variability in the share of short-term to total external debt and experienced a decrease in the reliance of deposit-taking corporations on short-term funding after 2010. EMEs are characterised by a more volatile trend in the share of short-term to total external debt. For example, in Korea, short-term debt relative to total debt in the banking sector decreased after 2009, a time when the country was most active in its introduction and tightening of CB-CFMs. In Turkey, however, more balanced use of tightening and easing actions on CB-CFMs may have resulted in a short-term external debt share that in 2013 almost reverted to its 2005 levels.

The paper empirically tests whether the increased use and tightening of CB-CFMs resulted in a reduction of total external debt of deposit taking corporations and especially in a contraction of the shortterm component, which was the target of most of the tightening actions on CB-CFMs.

A bank can borrow from a foreign lender either directly across the border or from an affiliate of a foreign bank. The first strategy entails a claim by a non-resident (the bank lender) to a resident (the bank borrower) and thus enters the balance of payments. The second strategy by contrast entails a loan from the foreign subsidiaries to the domestic bank and it is not recorded in the balance of payments. Since the World Bank data on external debt are constructed on consolidated basis, they include lending through affiliates, which represents a substantial share of international banking activity as illustrated in Figure 3, that draws on BIS data on intragroup lending and cross-border banking flows. Furthermore, cross-border lending steeply declined in the wake of the global financial crisis while lending through affiliates was more stable. ${ }^{10}$ The finding that international intragroup lending recovered to its pre-crisis level while crossborder lending did not seems to support the idea that the introduction of new regulations on cross-border banking operations could be part of the explanation for the "great retrenchment" of cross-border bank lending and that banks could circumvent the new rules by relying on foreign affiliates.

Figure 3. International bank-to-bank lending (1997-2015)

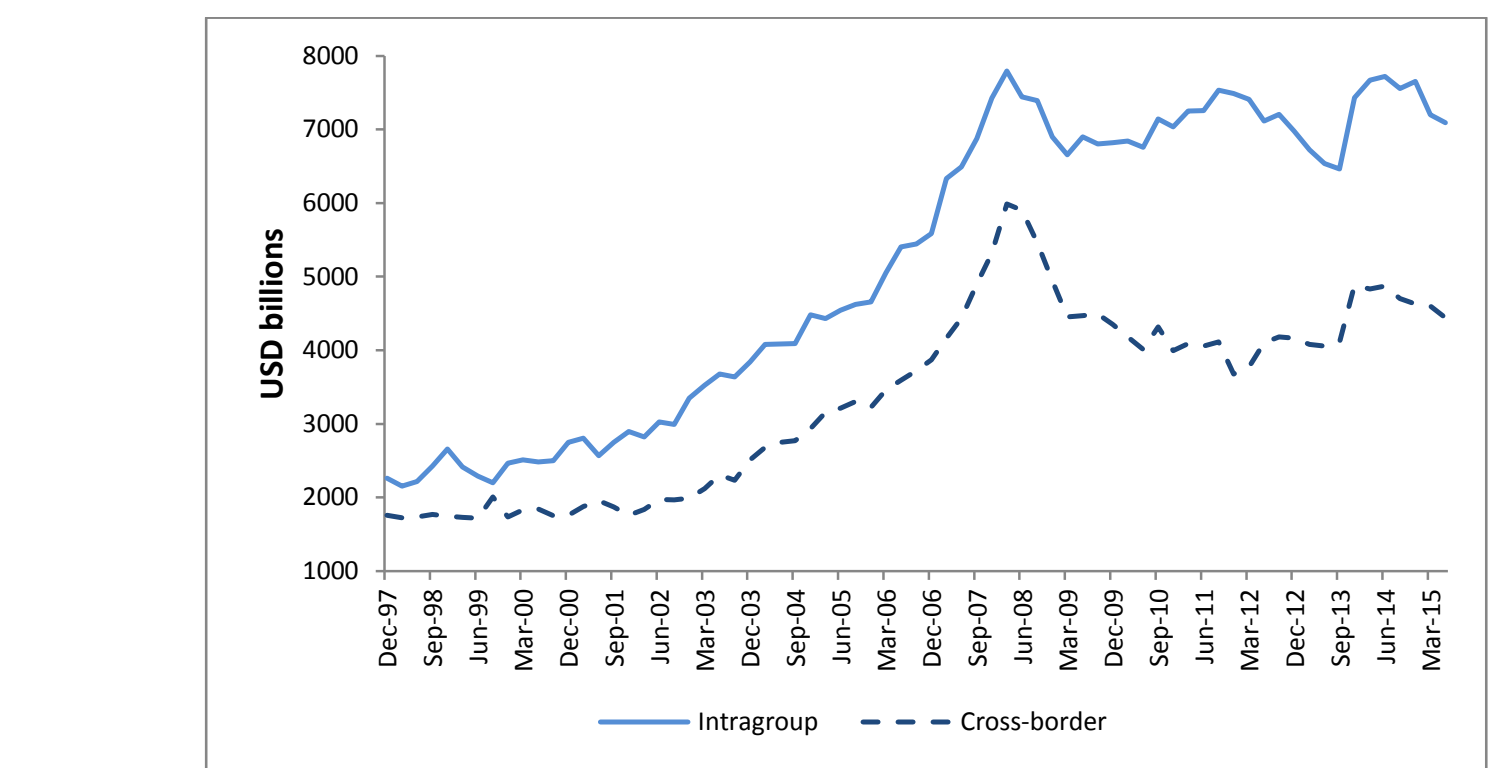

Source: OECD staff calculation from BIS Locational Banking Statistics Tables 5 data aggregated for Belgium, Denmark, Finland, Germany, Ireland, Japan, Luxembourg, Sweden, Switzerland, UK and US; countries for which information on intragroup lending is available.

\footnotetext{
${ }^{10}$ See also Milesi-Ferretti and Tille (2011) and IMF (2015).
} 
Data from the BIS Locational Banking Statistics are instead not consolidated and are registered on the basis of the residence principle, so they do not offset the positions between subsidiaries and the parent operating in different countries; therefore, they provide more accurate information on the aggregated operations of banking activity denominated in FX at country level.

\section{Data on CB-CFMs are taken from a novel dataset developed by the OECD}

The main explanatory variables use a dataset (De Crescenzio et al., 2015) which records changes (introduction, adjustment and removal) in the use of CBMs from 2005 to 2013 . The dataset includes policies affecting assets, liabilities, net positions and derivatives of banks. It also provides additional information regarding: i) the type of measure used; ii) the declared purpose; iii) the borrowers to whom the measure applies; iv) the institutions and agents to which the measure applies and v) whether the measure has to be activated or its parameters can be adjusted based on economic circumstances.

CBMs included in the original dataset encompass a broad category of measures, namely regulations imposing a different treatment between domestic and FX-denominated operations by banks. These CBMs may be addressed at operations amongst residents only, or at operations also with nonresidents. Within this latter broad category, CBMs may have the character of CFMs as they extend to operations abroad with non-residents. ${ }^{11}$

The indicator of policy changes $(C B C F M)$ takes the following values: +1 for tightening actions, 1 for loosening actions and 0 for no change. If multiple actions are undertaken within the same quarter their score is summed, so that $C B C F M$ can take on values bigger than 1 (smaller than -1) in case more than one tightening (loosening) action were implemented during a given quarter. This strategy has been largely adopted in the literature to capture the direction of the interventions of national regulators both for MPMs (Lim et al., 2011; Kuttner and Shim, 2013; Vandenbussche et al., 2012; Zhang and Zoli, 2014; Cerutti et al., 2016) and CFMs (Bruno et al., 2015; Ahmed et al., 2015).

An important caveat is that this approach may present some limitations since it does not measure the intensity of a given measure or action, when in practice some "tightening" actions may be more restrictive than others and some "easing" actions may be more liberalising than others. Nevertheless, as the literature has not currently overcome yet the challenge of measuring the intensity of actions, the approach followed in this study allows to compare the impact of an increase in banking regulation on different types of capital flows and banks' balance sheet and to assess how financial intermediaries adjust their activities to the introduction or increased use of new regulations.

\section{Data on domestic regulations, capital controls and on push and pull factors}

The model includes controls for domestic macro-prudential measures and capital controls, push and pull determinants of international capital flows and banking characteristics (Table 3 in Annex 3). In particular:

- Capital controls: Data on capital controls, i.e. restrictions that apply exclusively to non-residents, both on inflows and outflows come from the dataset built by Fernandez et al. (2015). More specifically, the analysis controls for an overall index of restrictions $(k a)$ as well as for restrictions

\footnotetext{
${ }^{11}$ As mentioned earlier, this paper focuses on CBMs that extend to operations abroad with non-residents and that thus have a character of CFMs, which are defined as CB-CFMs.
} 
in the financial sector specifically $(f c) .{ }^{12}$ An additional control is also used for regulations in the money market and on bond emission which are applied more frequently and can have an impact on external short-term and long-term banking debt, respectively.

- Macro-prudential policies: Data on domestic macro-prudential policies exclude measures that take the form of CFMs; information is taken from the replies to an International Monetary Fund's survey sent out in 2010. In particular, the analysis considers limits on loan-to-value ratio (ltv), limits on debt-to-income ratio $(d t i)$, reserve requirement $(r r)$ and dynamic provisioning $(d p)$ in order to control for measures affecting credit demand and supply. As data are not available for the period 2011-2013, including these controls drastically reduces the length of the sample by three years (the sample when controls for macro-prudential policies are included spans from the first quarter of 2005 to the last quarter of 2010). ${ }^{13}$

- Push factors: Controls for push (global) factors are also included, namely monetary policy rates and the aggregated size of balance sheets of Central Banks (European Central Bank, US Federal Reserve, Bank of England, Bank of Japan) as a proxy for conventional and unconventional monetary policies. The VIX index is also included, as measure of volatility and global risk aversion.

- Pull factors: The model includes nominal GDP, the spread between national and US interest rates, inflation, total public deficit, international reserves in foreign exchange, nominal exchange rate ${ }^{14}$ and a real estate price index.

- Banking variables: A measure of leverage is used, defined as bank capital to total assets to control for the domestic financial cycle, the non-interest income to total income as a measure of risk appetite of banks and banks' deposits over GDP as an indicator of financial development. The ratio of banks' credit to GDP is also included to disentangle the credit supply of the banking system. Everything else being kept equal, a higher ratio indicates a stronger intermediation activity. Finally, the model includes the share of FX claims over GDP as a measure of a country "dollarisation", i.e. the fact that domestic residents hold foreign currency or financial assets denominated in foreign currency as part of their asset portfolios (Reinhart et al., 2014).

The final dataset of banking variables, policy indicators and economic factors includes 18 countries and covers the period 2005-2013 at quarterly frequency. Annex 3 describes in details all the data used and their sources.

\footnotetext{
${ }^{12}$ The IMF's Annual Report on Exchange Arrangements and Exchange Restrictions (AREAER) reports the presence of rules and regulations for international transactions by ten categories of assets. $f c$ includes financial credit and credits other than commercial credits granted by all residents, including banks, to non-residents $(f c o)$, or vice versa $(f c i) . k a$ is an average of the scores for restrictions on all the asset categories.

${ }^{13}$ Tables 10 and $12-17$ in the Annexes refer to estimations conducted on yearly observations from the first quarter of 2005 to the last quarter of 2013. Table 11 instead refers to the restricted sample that we obtain when MPMs are included among the explanatory variables, and which spans from the first quarter of 2005 to the last quarter of 2010.

${ }^{14}$ For the purpose of this study, the model controls for the nominal exchange rate (USD per national currency). It would be interesting to also test for the effects of the Exchange Rate Regime (ERR). An IMF classification is available for de jure ERRs; however, de jure classifications may not reflect actual variations in the exchange rate, and empirical research has often made use of the nominal exchange rate variable to capture de facto movements in the exchange rate and changes in the ERR. Additionally, the use of CB-CFMs is particularly intense in countries with a managed exchange rate, which leads to our country sample being dominated by countries with a non-free floating ERR.
} 
External banking debt, and in particular the short-term component, exhibited strong pro-cyclicality during the crisis

A first step is the analysis of the composition of external debt, the cross-sectional differences and their evolution in the pre- and post-crisis period (before and after 2008Q4). Decomposing the debt by maturity, it is interesting to note that short-term debt accounts for a large share of external debt of banks in the sample, with the exception of Slovenia, Mexico, India, Hungary and Chile (Table 4 in Annex 4, and Figure 10 in Annex 6). For the whole sample this share remained unchanged in the pre- and post-crisis period, with external short-term debt accounting for about $53 \%$ of the total.

Summary statistics show the boom-bust dynamics of banking flows in the pre- and post-crisis period (Table 5 in Annex 4, and Figure 11 in Annex 6). For the whole sample, external debt registered on average a quarter-on-quarter growth by $5.26 \%$, in the eve of the crisis with the highest values registered in Chile, Hungary, Korea, Paraguay, Slovenia and Turkey. By contrast, it drastically slowed down in the wake of the crisis, declining on average to $1.2 \%$ for the whole sample, with strongest reductions in countries that experienced a large expansion before the crisis, especially Australia, Chile, Hungary, Korea, Singapore and Slovenia.

The pro-cyclicality of external debt is more pronounced in the short-term component. In the precrisis period the standard deviation of short-term debt is higher than that of total debt, confirming the instability of the short-term funding component and the risk of capital reversal and sudden stops. In addition, the difference in mean values in the pre- and post-crisis period is wider for short-term debt than for total debt. Finally, short-term debt was more volatile in the run up to the crisis for several countries (e.g. Brazil, Chile, India, Indonesia, Paraguay, Slovenia, Thailand and Turkey).

\section{Loans are the component of external banking debt which reduced most during the crisis}

The composition of external debt by instrument is very heterogeneous across countries (Tables 6 and 7 in Annex 4). Loans account for an overwhelming share of total external debt in Brazil, Colombia, Korea, Slovenia, Thailand and Turkey. This component includes unsecured interbank loans and secured loans, such as repurchase agreements (repos) and securities lending, which is an increasing source of funding for banks. In Australia, securities account for the largest share of external debt, while currency and deposits are the most important component in Chile, India, Israe ${ }^{15}$ and Singapore. For the whole sample, the share of loans reduced in the post-crisis, while securities and deposits increased. In particular, after the crisis loans fell in Hungary, Korea, Romania and Slovenia, while currency and deposits contracted in Hungary, Israel and Slovenia. Finally, for the whole sample currency and deposits are the funding that on average increased the most in the run up to the crisis and exhibit the highest degree of volatility (Table 8 in Annex 4).

Finally, when short-term debt is examined by component, it is worth noting that the share of loans contracted substantially from $42 \%$ to $37 \%$ of total short-term debt between pre- and post-crisis period. In contrast, currency and deposits increased from $44 \%$ to $54 \%$ (Figures 4 and 5).

\footnotetext{
${ }^{15}$ The statistical data for Israel used in this paper are supplied by and under the responsibility of the relevant Israeli authorities. The use of such data by the OECD is without prejudice to the status of the Golan Heights, East Jerusalem and Israeli settlements in the West Bank under the terms of international law.
} 
Figure 4. Share of debt instruments to total external banking debt

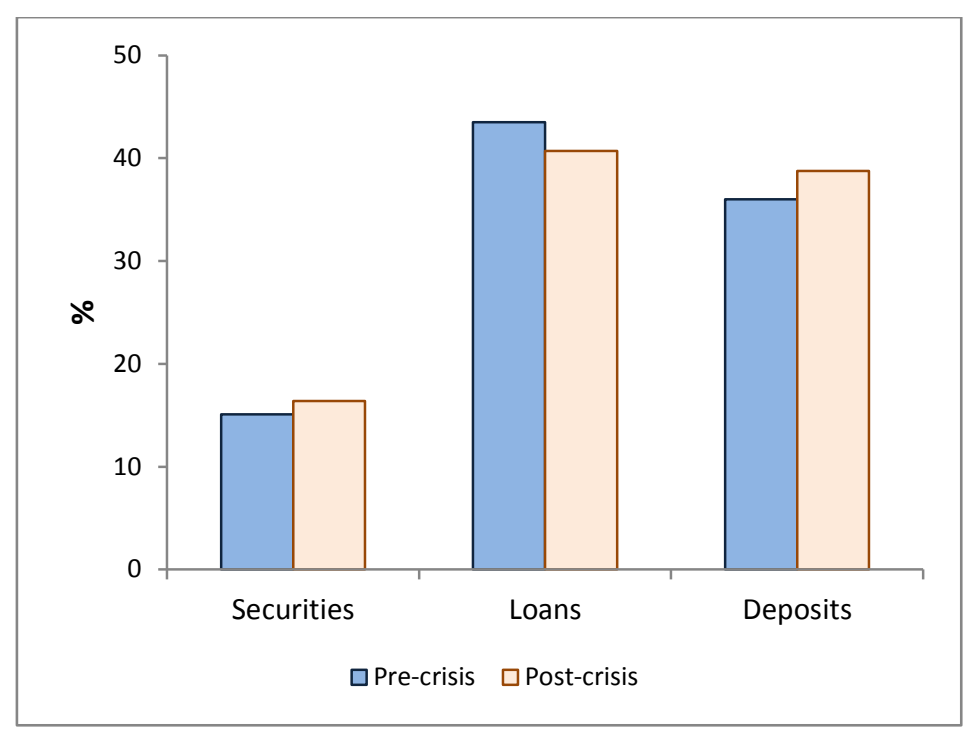

Source: OECD staff calculation and World Bank's Quarterly External Debt Statistics database.

Figure 5. Share of debt instruments to short-term external banking debt

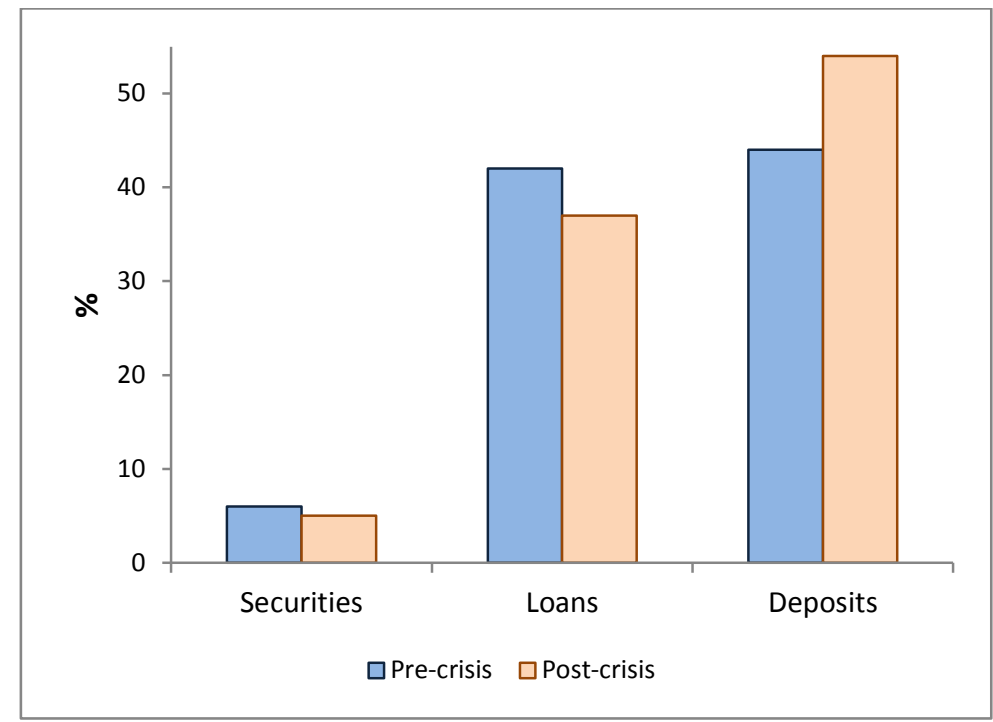

Source: OECD staff calculation and World Bank's Quarterly External Debt Statistics database.

\section{Countries increased their use of CB-CFMs in the aftermath of the recent global financial crisis}

The use of CBMs has increased in the post-crisis period, as this has become an active policy area. While the pre-crisis period is characterised by a large use of conventional measures, such as the regulation of the net FX position of banks, other types of CBMs were also increasingly used in the post-crisis period, ranging from taxes on FX liabilities to rules limiting FX derivatives (De Crescenzio et al., 2015). In particular, CBMs have been a common policy tool among EMEs, also within the OECD group. In the original OECD dataset, EMEs accounted for almost $92 \%$ of total actions recorded. 
Within the sample, the most active users of CBMs have been Turkey and India, with $21 \%$ and $17 \%$ of total actions recorded respectively (Figure 6).

More than $40 \%$ of all the actions on CBMs target banks' liabilities. In particular, differentiated reserve requirements and regulation of domestic as well as foreign currency deposit accounts are the most common categories of CBMs targeting banks' liabilities.

Figure 6. Distribution of actions on CB-CFMs across countries (2005-2013) ${ }^{16}$

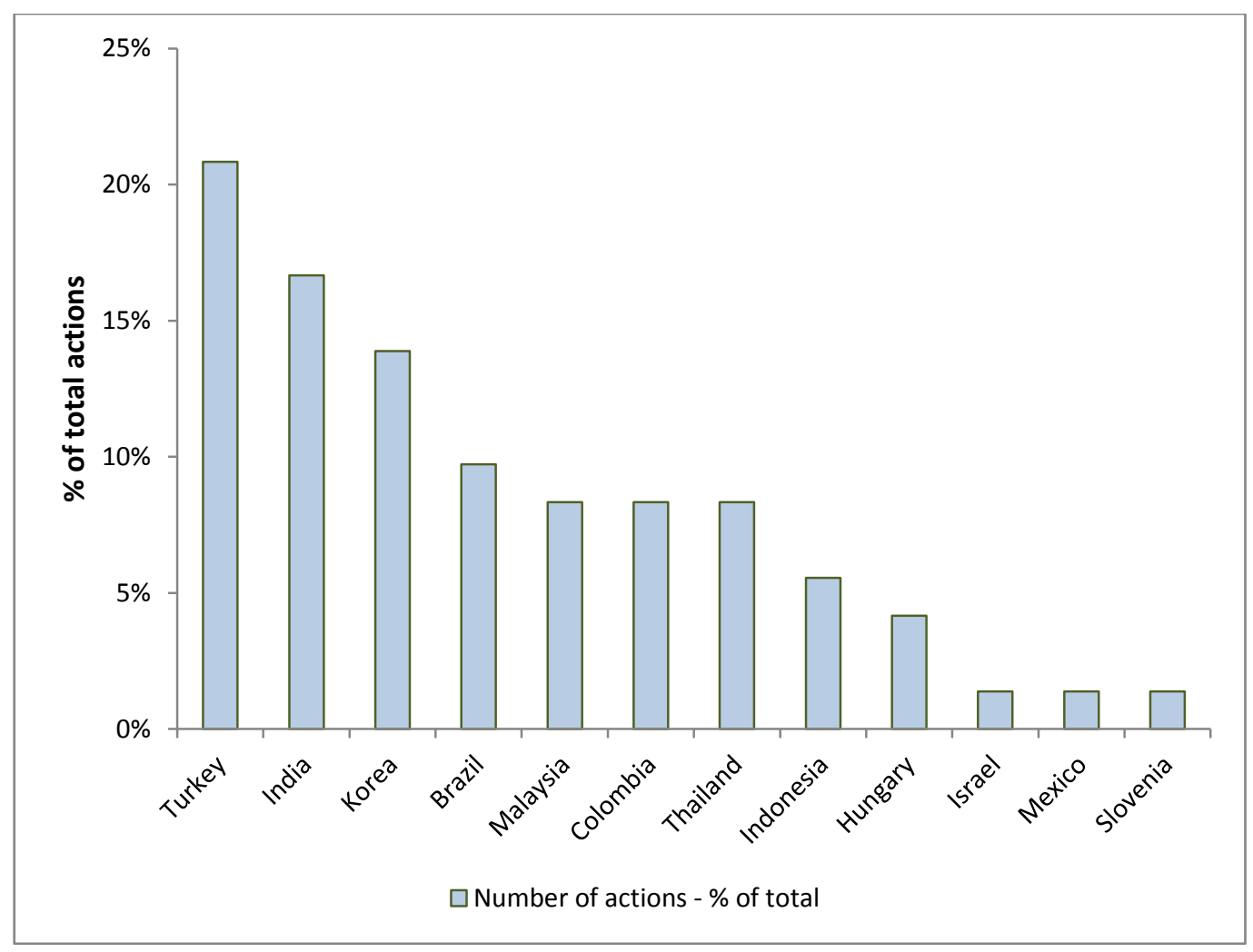

Source: OECD staff calculation from De Crescenzio et al. (2015).

Trends in the directionality of use of CBMs vary greatly among countries (Figure 7); in particular, whilst some countries like Turkey, Colombia and India have made a balanced use of tightening and easing actions, other countries increasingly regulated bank operations in FX, as for example Korea, Indonesia and Hungary. Finally, Malaysia and Thailand stand out for having overall liberalised their CBM stance, in line with a general liberalising trend of non-OECD South-East Asian EMEs that has been highlighted in De Crescenzio et al., 2015.

\footnotetext{
${ }^{16}$ Graphs on the use of CB-CFMs include only countries that are part of the sample for this study and that made use of CB-CFMs over 2005-2013. Other countries included in the original dataset from De Crescenzio et al. (2015) but excluded from this analysis have not been displayed in this graph. Countries have been excluded from the country sample in this study either because no data were available on the external debt of deposit-taking corporations or because the CBMs implemented are considered standard macro-prudential measures and are not the focus of this study.
} 
Figure 7. Directionality of actions on CB-CFMs across countries (2005-2013)

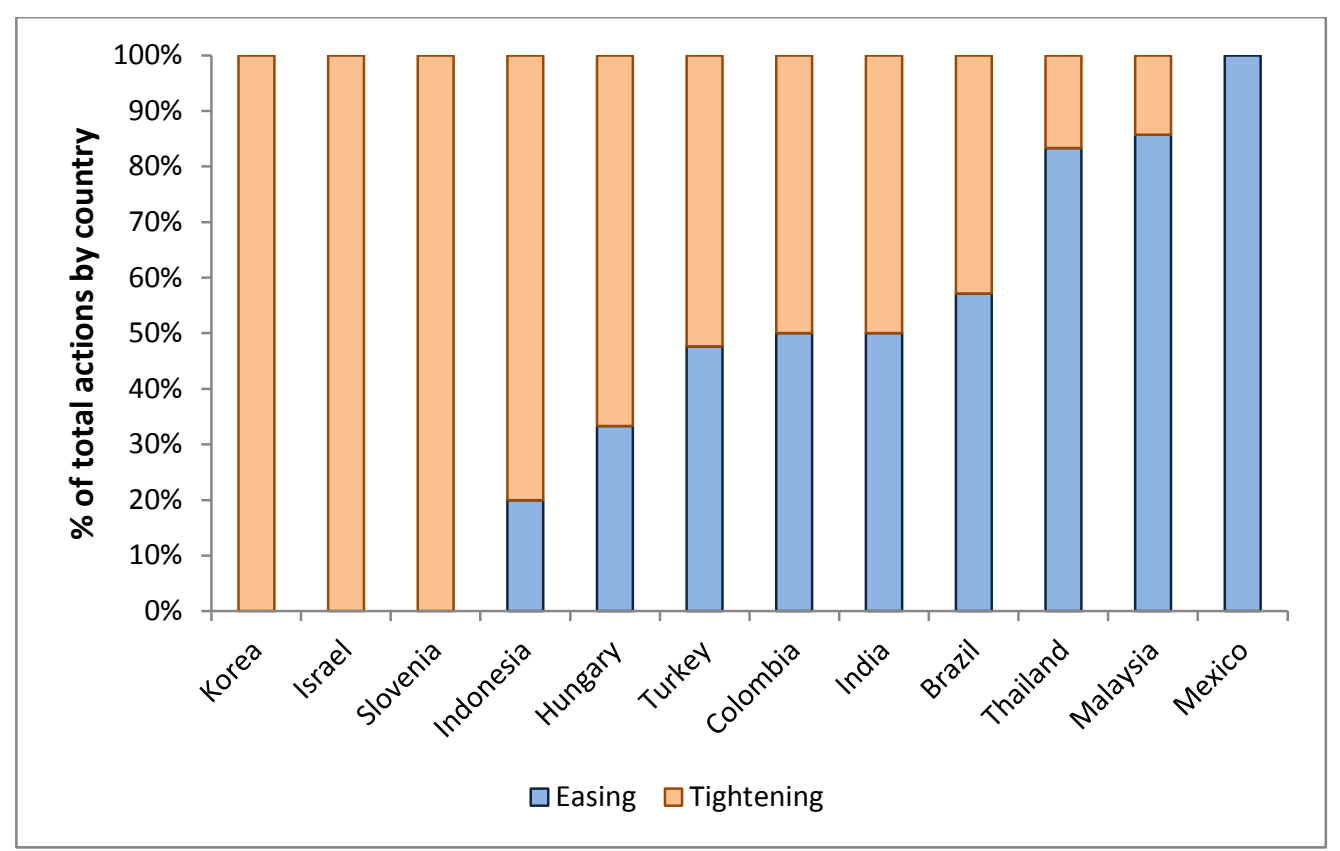

Source: OECD staff calculation from De Crescenzio et al. (2015).

The largest use of CBMs in the sample was recorded in the aftermath of the recent global crisis, with a third of total measures being implemented over 2010-2011. We record more tightening than easing actions overall. The implementation of tightening actions has been particularly intense in the years 2010 and 2011, with 17 actions in total. Easing actions have instead peaked in 2008 and 2012 (Figure 8).

Figure 8. Tightening and easing actions (2005-2013)

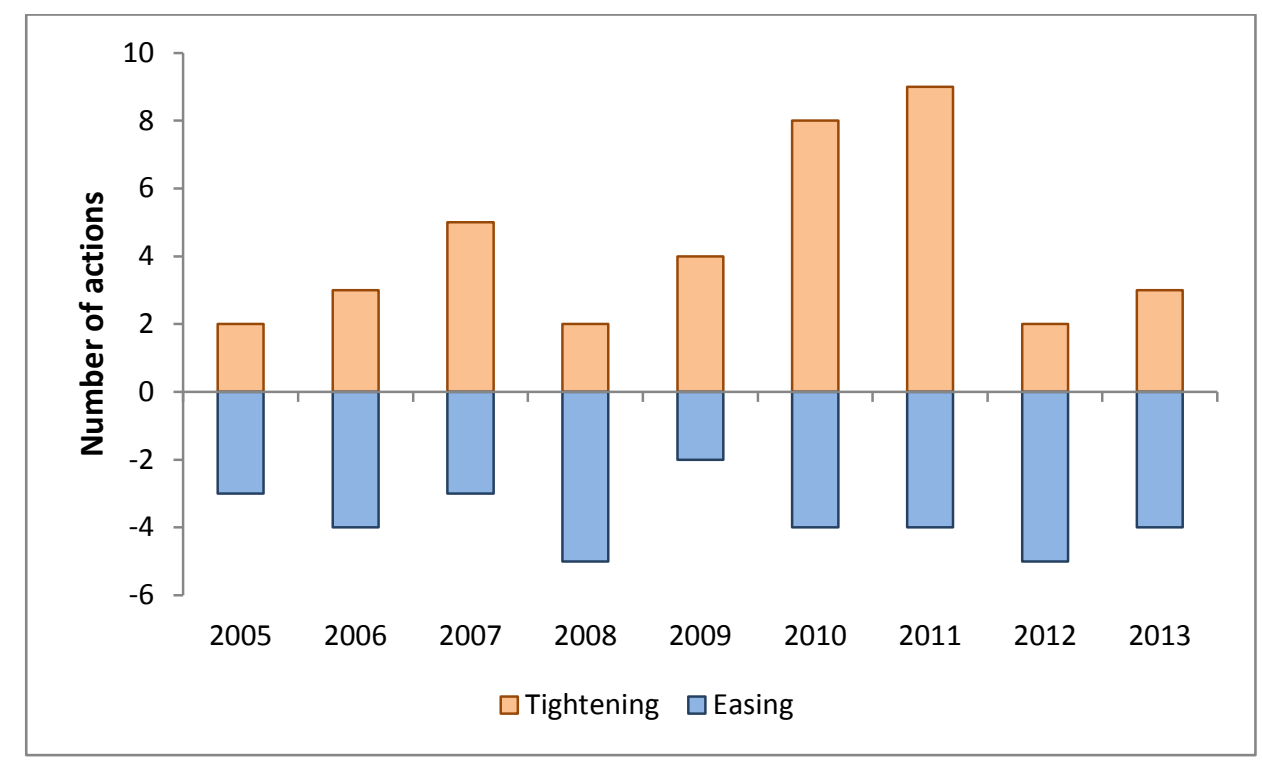

Source: OECD staff calculation from De Crescenzio et al. (2015). 


\section{EMPIRICAL MODEL AND RESULTS}

\section{The empirical model}

The empirical mode $1^{17}$ exploits panel regressions with random effects ${ }^{18}$, as some of the countries in the panel did not make use of CB-CFMs, and standard errors that are clustered at the country level. ${ }^{19}$ The baseline specification looks as follows:

$$
Y_{i t}=\alpha+\beta C B C F M_{i t-1}+\Gamma X_{i t-1}+u_{i t}
$$

Where:

- $\quad Y_{i t}$ is the rate of growth (given by the quarterly log-difference) of total external debt of deposit taking institutions, its components by maturity (short-term and long-term external debt) and by instruments (loans, securities and currency and deposits);

- CBCFM $_{i t-1}$ is the policy variable that represents changes in the use of CB-CFMs. This main explanatory variable is lagged by one quarter to account for the delay between the introduction of a measure and its effect on the dependent variables; lagging the policy variable by one quarter also addresses potential endogeneity concerns.

- $\quad X_{i t-1}$ is a vector of controls that include both push and pull factors as well as other capital control and macroprudential measures; and

- $u_{i t}$ is a random disturbance.

All control variables are lagged by one quarter to reduce endogeneity concerns. The dependent variables are regressed on the index of changes in the use of CB-CFMs and for the long-term effects of our policy change index are tested by introducing both the first and second lag of the policy variable $C B C F M$ in the specifications.

The different effects of CB-CFMs before and after the global financial crisis are controlled by interacting the policy index with a dummy variable that takes the value of 1 for every quarter in and after 2009 and 0 otherwise (post-2009) and a second dummy variable that takes the value of 1 in every quarter before 2009 and 0 otherwise (pre-2009).

\footnotetext{
${ }^{17}$ A dynamic component in the model could be added; however, we have included a dynamic component in the difference GMM estimator, so the robustness of our results to the addition of a dynamic component is tested there. Autocorrelation is also addressed in the robustness test.

${ }^{18}$ The Hausman test has been run and it confirms that the assumption of random effects is valid.

${ }^{19}$ The econometric strategy chosen is the same as Bruno and Shin (2014), and Bruno, Shim and Shin (2015).
} 
Finally, to further address potential issues arising from endogeneity of policy variables, robustness tests were performed and the difference GMM estimator developed by Arellano and Bond (1991) and Arellano and Bover (1995) was exploited, which controls for country-specific effects and accounts for endogeneity in the explanatory variables.

To avoid instrument proliferation, the number of lags chosen as instruments for the endogenous variables was limited to a maximum of three. The instruments were also collapsed into smaller sets. Standard errors were estimated as robust to heteroscedasticity and autocorrelation within countries, to address the risk of potential downward bias in the standard errors due to the high number of instruments.

As the Sargan test is not consistent with non-spherical errors, the Hansen test is reported to assess the instrument validity, even though the limited number of GMM instruments should guarantee the robustness of this test. Overall, the regressions perform well on the over identification tests and the Hansen's test confirms the validity of lagged variables as instruments. The test for first- and second-order serial correlation is also reported. The null hypothesis of no second-order serial correlation for all specifications cannot be rejected but it can for first-order serial correlations, as required by the specification.

\section{Main results}

\section{CB-CFMs reduce cross-border banking flows}

This study suggests that CB-CFMs are policy instruments that contribute to the reduction of cross-border banking flows one quarter after their implementation. The analysis first assesses the impact of the policy variable $C B C F M$ on the rate of growth of total cross-border banking flows, measured as the external debt of banks reported in the World Bank's QEDS database. Table 10 shows that the introduction of a new CB-CFM or the tightening of an existing measure result in a decrease, albeit not significant, of external debt in the banking sector, controlling for several macroeconomic and banking push and pull factors.

Both push and pull factors are found to affect cross-border banking flows. In particular, the external debt of banks increases following a reduction of the VIX index and currency appreciation. ${ }^{20}$ The risk aversion and leverage of global banks are primary forces pushing cross-border banking flows from the centre to the periphery of the financial system. Furthermore, the accumulation of large volumes of unhedged positions in FX of financial institutions makes countries more exposed to exchange rate movements through the valuation channel (Lane and Milesi-Ferretti, 2005) and intensifies the leverage cycle. During booms and large capital inflows, currency appreciation strengthens the balance sheet of banks, increasing their lending capacity and making external debt more attractive. However, during bursts, capital outflows and currency depreciation exacerbate the deleveraging of banks. Conventional and unconventional monetary policy in the centre of the financial system, proxied respectively by the spread of domestic and US policy rates and the size of the balance sheet of main central banks are not found to have an explanatory power on external debt. However, by affecting the VIX they may have an indirect effect on cross-border banking flows.

Concerning pull factors, the coefficients of GDP growth and the credit-to-deposit ratio are significant and positive, which suggests that domestic economic forces capture the relative attractiveness

\footnotetext{
${ }^{20}$ Several papers find that push factors are a primary determinant of banking flows (Cerutti et al. (2014). They are particularly relevant for capital inflows in EMEs (Calvo et al. 1993, Cerutti et al. 2015) and also for bond and equity flows (Sarno et al., 2015).
} 
of different destinations for investment opportunities. Moreover, banks tend to rely on non-core funding to increase their credit activity borrowing from non-resident lenders. During upturn phases, when banks reach the maximum level of core deposits to finance their activity, non-core deposits and in particular external debt become a key source of funding (Shin, 2012).

Also the impact of FX reserves is assessed, which can be also used as a capital flow management tool to avoid currency appreciation. An increase in FX reserves would exert a downward pressure on the exchange rate reducing gross banking inflows (Blanchard et al. 2015). However, Table 10 shows that their impact on external debt of banks is not significant.

Finally the impact of domestic MPMs (Table 11) on the external debt of banks is considered: these results should be evaluated with caution, since when domestic MPMs are included the length of the sample substantially reduces due to data gaps and is largely limited to the pre-crisis period. Interestingly, some domestic MPMs also seem to contribute to a reduction of cross-border banking flows: a loosening in the debt-to-income ratio for example is associated with a rise in international banking flows one quarter after the implementation of the change. It is to be noted however that results are not confirmed when robustness checks are performed and the difference GMM estimator is exploited.

\section{CB-CFMs have a stronger impact on short-term debt and interbank borrowing}

The external debt of banks is then broken down by maturity (short-term and long-term) and debt instruments (loans, securities, currency and deposits) in order to more granularly assess the impact of CBCFMs on different debt components (Tables 12 to 20). The hypothesis is tested that CB-CFMs significantly reduce the short-term component of external debt, which is targeted by the majority of the measures introduced with the aim of reducing capital flow volatility. Data for all dependent variables come from the World Bank's QEDS database.

The main results are that $\mathrm{CB}-\mathrm{CFMs}$ are indeed most effective in reducing short-term external debt and loans. These results indicate that the impact of CB-CFMs is negative and significant on short-term external debt, while negative but not significant on long-term external debt. This result can be interpreted in light of the fact that most of the tightening actions of CB-CFMs target short-term liabilities, which constitute the most volatile component and a major source of financial instability in the banking sector, and aim at changing the composition of banking flows towards safer and more stable flows.

Indeed, the stated objective of the vast majority of CB-CFMs is to enhance financial stability. In this context, the benefits of CB-CFMs should be analysed to understand whether these measures have costs in terms of decreased financial openness that are proportionate to the risks they aim at addressing and to the enhancement of financial stability that they may bring.

A check is also run to see whether CB-CFMs may induce a reallocation of debt from short-term to long-term instruments which may happen with a lag: CB-CFMs are found to have a positive, albeit not significant, impact on long-term banking flows two quarters after their implementation (Table 15).

In order to look at whether the effect of CB-CFMs may have changed in the post-2009 period, during which banks went through the so-called "great deleveraging", the policy variable $C B C F M$ is interacted with a dummy variable equal to 1 in every quarter in or after 2009 and 0 otherwise (post-2009), and a second dummy variable equal to 1 in every quarter before 2009 and 0 otherwise (pre-09). The results indicate that CB-CFMs are most effective in reducing the rate of growth of short-term external debt in the pre-2009 period, whilst their effect is negative but not significant (and smaller in magnitude) after 2009 (Table 13). 
Regarding debt instruments, CB-CFMs seem to negatively affect all external debt components but results are significant only for loans. The latter is also the component that "retrenched" the most in the aftermath of the crisis. Looking at those CB-CFMs that directly target bank liabilities, it is worth noting that measures on FX deposits generally correspond to the opening of FX accounts, so this could explain why the impact of CB-CFMs on currency and deposits is not significant. Interestingly, in the sample there are no measures directly restricting interbank borrowing, such as restrictions on money market instruments (see Fernandez et al. 2015). Nevertheless, CB-CFMs, by reducing the intermediation activity of banks, tend to reduce the source of funding used by banks to lever up (Adrian and Shin, 2010).

Robustness checks are performed to address endogeneity concerns in the specifications. Results reported in Tables 16 and 18 confirm that CB-CFMs contribute to a significant reduction in the rate of growth of the short-term component of the external debt of banks, as well as in the rate of growth of loans.

Finally, a check is run on whether CB-CFMs affect the composition of banks' balance sheet and in particular FX-denominated liabilities, which as mentioned account for a considerable share of crossborder banking flows (see Figure 2). Data for FX liabilities, both towards residents and non-residents, come from the BIS Locational Banking Statistics. 


\section{CONCLUSIONS AND POSSIBLE AREAS OF FUTURE WORK}

In the wake of the financial crisis, international authorities increasingly resorted to the use of a new class of banking regulations that discriminate on the basis of the currency of an operation and that fall in a grey area between macro-prudential and capital control measures. This paper reviews trends of international banking flows in the pre- and post-crisis period and assesses the impact of CB-CFMs, which are a subset of CBMs that also extend to operations with non-residents, on cross-border banking flows. The paper finds that even though these regulations do not discriminate on the basis of the residency of the counterparty, they contribute to a reduction of not only the debt of banks that is denominated in FX, but also banking debt held by non-residents. Therefore, these new regulations could share the drawbacks of traditional CFMs of creating price distortions and may raise issues regarding international commitments to cross-border openness.

More specifically, the impact of these measures is stronger for short-term external debt than for long-term debt, which is in line with EMEs increasingly regulating short-term capital inflows, which are typically more volatile and subject to sudden stops and reversals. When decomposing the external debt of banks by instrument, the empirical findings suggest that CB-CFMs are more effective in reducing loans than securities or deposits. CB-CFMs thus affect the composition of international banking flows, as opposed to traditional macro-prudential regulation, which do not have a significant effect on the external debt of banks.

The debate on the use of CB-CFMs has been lively as countries, and especially EMEs, have been increasingly active in this field; the empirical evidence on the impact of these measures, however, is still scant. The main body of literature has focused on standard capital controls and MPMs, without specifically looking at CBMs that are also CFMs in a systematic way. As such measures are becoming an active policy area, further research could focus on: i) the impact of specific classes of measures on bank balance sheets, using in particular micro-data; ii) spill overs within the country enacting them (e.g. on the non-financial sector) and across countries; iii) different metrics to capture the intensity of policy actions; iv) the interaction of different policy tools and finally v) the potential short-term and long-term benefits of currency-based measures in terms of financial stability. For this last point, it would be interesting to investigate the capacity of CB-CFMs to reduce currency mismatches in bank balance sheets and the impact on financial instability, measured as excessive credit growth in terms of deviation from the trend, both in the short- and long-term.

The analysis in this paper could also be extended in several directions to look at the impact of CB-CFMs on other types of international capital flows.

First, the effect of CB-CFMs on total capital flows could be assessed and how this effect changes with the relative size of the banking sector in a country.

Second, it could be interesting to test whether these measures can contribute to explaining the substitution effect of capital inflows between the banking and non-banking channels in EMEs. Recent studies find that unconventional monetary policy in advanced economies favoured corporate bond issuance in EMEs (Fratzscher et al. 2013; Gilchrist et al. 2014; Lo Duca et al. 2014) and this trend could be reinforced by the introduction and tightening of CB-CFMs, which lead to a disintermediation process in the banking system. 
Another interesting question is the impact of these regulations on exchange rate dynamics. The empirical results could shed more light on the economic rationale behind the introduction of CB-CFMs and on whether the primary objective of policy makers is to dampen the credit cycle or to control the exchange rate (Blundell-Wignall and Roulet, 2013).

Finally, central banks argue that the introduction of CB-CFMs can alleviate their role as lenders of last resort in foreign currency, a role that forces them to hoard precautionary international reserves. Further studies could test whether the implementation of these regulations or a change in their policy stance reduced the accumulation of foreign exchange reserves and the responsiveness of central banks to the global credit cycle (see Blundell-Wignall and Roulet (2015)), or whether this reduction is instead the result of exchange rate interventions to defend the domestic currency vis-à-vis a tightening of US monetary policy.

As a concluding note of caution, it is important to highlight the limitations of empirical analyses in estimating the impact and effectiveness of policy actions, some of which have already been described in previous sections. In this context, it should be recognised that an empirical analysis can be a complex and sensitive task, but at the same time including such elements in the dialogue over specific classes of measures would allow for a more informed and complete discussion on the risks regulators are trying to address, and the specific costs and benefits such measures may entail. 


\section{REFERENCES}

Adrian, T. and H. S. Shin, 2013. Procyclical Leverage and Value-at-Risk. NBER Working Papers 18943, National Bureau of Economic Research, Inc.

Adrian, T. and H. S. Shin, 2010. Liquidity and Leverage. Journal of Financial Intermediation 19(3), pp. 418-437.

Aghion, P., P. Bacchetta, and A. Banerjee, 2004. A corporate balance-sheet approach to currency crises. Journal of Economic Theory, Elsevier, vol. 119(1), pages 6-30, November.

Aghion, P., P. Bacchetta, and A. Banerjee, 2000. A simple model of monetary policy and currency crises. European Economic Review, Elsevier, vol. 44(4-6), pages 728-738, May.

Ahmed, S., S. Curcuru, F. Warnock, and A. Zlate, 2015. The Two Components of International Capital Flows. Working Paper.

Ahrend, R., A. Goujard, and C. Schwellnus, (2012), "International Capital Mobility: Which Structural Policies Reduce Financial Fragility?", OECD Economic Policy Papers, No. 2, OECD Publishing, Paris. http://dx.doi.org/10.1787/5k97gkcv5z27-en

Arellano, M. and O. Bover, 1995. Another look at the instrumental variable estimation of errorcomponents models, Journal of Econometrics, Elsevier, vol. 68(1), pages 29-51, July.

Avdjiev, S., M. Chui, and H. S. Shin, 2014. Non-Financial Corporations from Emerging Market Economies and Capital Flows. BIS Quarterly Review, December 2014.

Baba, C. and A. Kokenyne, 2011. Effectiveness of Capital Controls in Selected Emerging Markets in the 2000s. IMF Working Paper, WP/11/281.

Bacchetta, P., 2000. Monetary Policy with Foreign Currency Debt. Working Papers 00.03, Swiss National Bank, Study Center Gerzensee.

Beirne, J. and C. Friedrich, 2014. Capital Flows and Macroprudetial Policies - A Multilateral Assessment of Effectiveness and Externalities. European Central Bank Working paper Series, No 1721.

Bekaert, G. Ehrmann, M. Fratzscher and A. Mehl, 2011. Global crises and equity market contagion. European Central Bank Working Paper Series, No 1382.

Bekaert, G., M. Hoerova and M. Lo Duca, , 2013. Risk, uncertainty and monetary policy. Journal of Monetary Economics, Elsevier, vol. 60(7), pages 771-788.

Bénétrix, A. S., P. R. Lane and J. C. Shambaugh, 2015. International currency exposures, valuation effects and the global financial crisis. Journal of International Economics, Elsevier, vol. 96(S1), pages S98S109.

Blanchard, O., G. Adler, and I. de Carvalho Filho, 2015. Can Foreign Exchange Intervention Stem Exchange Rate Pressures from Global Capital Flow Shocks?, NBER Working Paper 21427.

Blundell, R. and S. Bond, 1998. Initial conditions and moment restrictions in dynamic panel data models. Journal of Econometrics, Elsevier, vol. 87(1), pages 115-143, August.

Blundell-Wignall, A. and C. Roulet, 2016. "Evaluating capital flow management measures used as macroprudential tools", OECD Journal: Financial Market Trends, Vol. 2015/2. http://dx.doi.org/10.1787/fmt-2015-5jm0p44dlq6f.

Blundell-Wignall, A. and C. Roulet, 2014. "Problems in the international financial system", $O E C D$ Journal: Financial Market Trends, Vol. 2014/1. http://dx.doi.org/10.1787/fmt-2014-5jxzmkg91s0t. 
Blundell-Wignall, A. and C. Roulet, 2014. Problems in the International Financial System. OECD Journal: Financial Market Trends, vol. 2014/2, No. 107 Paris. http://dx.doi.org/10.1787/fmt-20145jxzmkg91s0t.

Bordo, M.D. and C. M. Meissner, 2005. "The Role of Foreign Currency Debt in Financial Crises: 18801913 vs. 1972-1997”. National Bureau of Economic Research, NBER Working Paper Series, No. 11897.

Bremus, F., Fratzscher, M., 2014. "Drivers of structural change in cross-border banking since the global financial crisis".

Broner, F., T. Didier, A. Erce, and S. Schmukler, 2013. "Gross capital flows: Dynamics and crises", Journal of Monetary Economics, Elsevier, Vol. 60(1), pages 113-133.

Bruno, V., I. Shim and H. S. Shin, 2015. "Comparative Assessment of Macroprudential Policies". BIS Working Paper, No 502.

Bruno, V., H. S. Shin, 2014. "Cross-Border Banking and Global Liquidity", BIS Working Papers, No 458.

Bussière, M., J. Schmidt, N. Valla, 2016. "International Financial Flows in the New Normal: Key Patterns (and Why We Should Care)", CEPII Policy Brief N. 10 March.

Calvo, G. A., L. Leiderman, and C. Reinhart, 1996. "Capital Flows to Developing Countries in the 1990s: Causes and Effects”. Journal of Economic Perspectives 10, Spring, 123-139.

Calvo, G. A., L. Leiderman, and C. Reinhart, 1993. "Capital Inflows and Real Exchange Rate Appreciation in Latin America: The Role of External Factors". IMF Staff Papers, 40(1), 108-151.

Calvo, G., 1998. "Capital Flows and Capital Market Crises: The Simple Economics of Sudden Stops”. Journal of Applied Economics, 1.

Calvo, G.A. and C.M. Reinhart, 2000. "When Capital Inflows Come to a Sudden Stop: Consequences and Policy Options". In P.B. Kenen and A.K. Swoboda (eds.) Reforming the International Monetary and Financial System, International Monetary Fund, pp 175-201.

Calvo, G.A. and E. Talvi, 2005. "Sudden Stops, Financial Factors and Economic Collapses in Latin America: Lessons from Argentina and Chile". NBER Working Paper No. 11153.

Catão, L. A.V. and G. M. Milesi-Ferretti, 2014. "External liabilities and crises”. Journal of International Economics, Elsevier, vol. 94(1), pages 18-32.

Cerutti, E., S. Claessens, and L. Ratnovski, 2014, "Global Liquidity and Drivers of Cross-Border Bank Flows". IMF Working Paper, 2014/69.

Cerutti, E., R. Correa, E. Fiorentino, and E. Segalla, 2016, "Changes in Prudential Policy Instruments-A New Cross-Country Database”, IMF Working Paper, 2016/110.

Cetorelli, N., and L. Goldberg, 2012. "Banking Globalization and Monetary Transmission". Journal of Finance 67(5): 1811-843.

Chang, R. and A. Velasco, 1999. "Liquidity Crises in Emerging Markets: Theory and Policy". National Bureau of Economic Research, NBER Working Paper Series, No. 7272.

Chung, K., J. Lee, E. Loukoianova, H. Park and H. S. Shin, 2014. "Global Liquidity through the Lens of Monetary Aggregates". IMF Working Paper 14/9, January.

Danielsson, J., H. S. Shin, and J. P. Zigrand, 2011. "Balance sheet capacity and endogenous risk". LSE Research Online Documents on Economics 43141, London School of Economics and Political Science, LSE Library. 
De Crescenzio, A., M. Golin and A. Ott (2015), "Currency-based measures targeting banks - Balancing national regulation of risk and financial openness", OECD Working Papers on International Investment, No. 2015/03, OECD Publishing, Paris. http://dx.doi.org/10.1787/5jrp0z9lp1zr-en.

Federal Reserve Bank of San Francisco (2013), Keynote address at 2013 Federal Reserve Bank of San Francisco Asia Economic Policy Conference.

Fernández, A., A. Rebucci and M. Uribe, 2014. “Are Capital Controls Countercyclical?”. New York, United States: Columbia University. Mimeographed document.

Fernández, A., M. W. Klein, A. Rebucci, M. Schindler and M. Uribe, 2015. "Capital Control Measures: A New Dataset". IMF Working Paper, WP/15/80.

Financial Stability Board (FSB), 2015. "Corporate Funding Structures and Incentives".

Forbes, K. J. and F. E. Warnock, 2012. "Capital Flow Waves: Surges, Stops, Flight and Retrenchment". Journal of International Economics, vol 88, no 2, pp 235-251.

Forbes, K., M. Fratzscher, T. Kostka and R. Straub, 2012. "Bubble Thy Neighbor - Portfolio Effects and Externalities from Capital Controls". European Central Bank Working Paper Series, No 1456.

Forbes, K., 2014. " Financial "deglobalization"?: capital flows, banks, and the Beatles". Speech given at Queen Mary University, London, on Tuesday 18 November 2014.

Forbes, K., D. Reinhardt and T. Wieladek, 2015. "The Spillovers, Interactions, and (Un)Intended Consequences of Monetary and Regulatory Policies". Paper presented at the 16th Jacques Polak Annual Research Conference Hosted by the International Monetary Fund, Washington, DC-November 5-6, 2015

Fostel, A. and J. Geanakoplos. 2008. "Leverage Cycles and the Anxious Economy". American Economic Review 98, no. 4:1211-44.

Fratzscher, M., 2011. "Capital Flows, Push Versus Pull Factors and the Global Financial Crisis". European Central Bank Working Paper Series, No 1364.

Fratzscher, M., M. Lo Duca and R. Straub, 2015. "On the International Spillovers of US Quantitative Easing”. IMES Discussion Paper Series 15-E-07, Institute for Monetary and Economic Studies, Bank of Japan.

Fratzscher, M., M. Lo Duca, and R. Straub. 2013. "On the International Spillovers of U.S. Quantitative Easing”. ECB Working Paper 1557, European Central Bank, Frankfurt.

Galati, G. and R. Moessner, 2014. "What do we know about the effects of macroprudential policies?". De Nederlandsche Bank, Working Paper No 440.

Gilchrist, S., V. Yue, and E. Zakrajsek. 2014. "U.S. Monetary Policy and Foreign Bond Yields". Paper presented at the 15th Jacques Polak Annual Research Conference, Washington, November 13-14.

Ghosh, A.R., K. Jun, M. S. Qureshi and J. Zalduendo, 2012. "Surges”. IMF Working Paper WP/12/22.

Gourinchas, P.O. and M. Obstfeld, 2012. "Stories of the Twentieth Century for the Twenty-First". American Economic Journal: Macroeconomics, American Economic Association, vol. 4(1), pages 226-65, January.

Habermeier, K., A. Kokenyne and C. Baba, 2011. The Effectiveness of Capital Controls and Prudential Policies in Managing Large Inflows. IMF Staff Discussion Note SDN/11/14.

Houston, J. F., C. Lin, Y. Ma, October 2012. "Regulatory Arbitrage and International Bank Flows". Journal of Finance 67 (5), 1845-1895. 
Huefner, F., R. Koepke and P. Suttle, 2013. “Capital Flows to Emerging Market Economies”. International Institute of Finance Research Note, January 2013.

International Institute of Finance. 2016. “Capital Flows to Emerging Markets”. January 2016.

International Institute of Finance. 2015. "Emerging Markets—The Perfect Storm?”. August 2015.

IMF, 2015, “Global Financial Stability Report”, April 2015.

IMF (2014), “Global Liquidity: Issues for Surveillance”. Policy Paper, April 2014.

IMF 2011. "Macroprudential Policy: An Organizing Framework". Prepared by the Monetary and Capital Markets Department.

IMF (2010), "Global Financial Stability Report”. April 2010.

Kalemli-Ozcan, S., S. Bent and Y. Sevcan, 2012. "Leverage across firms, banks, and countries". Journal of International Economics, Vol. 88, $\mathrm{N}^{\circ} 2$, pp. 284-298.

Kalemli-Ozcan, S., 2014. "Why Turkey is Rebelling”. Project Syndicate.

Kaminsky, G. and C. M. Reinhart, 1999. "The Twin Crises: The Causes of Banking and Balance-ofPayments Problems". American Economic Review, 89(3), pp. 473-500.

Klein, M.W., 2012. "Capital Controls: Gates versus Walls”. Brookings Papers on Economic Activity 2012 (Fall): 317-355.

Krugman, P., 1999. "Balance Sheets, the Transfer Problem, and Financial Crises. International Tax and Public Finance". Springer, vol. 6(4), pp. 459-472, November.

Lane, P. R. and J. C. Shambaugh, 2010. "Financial Exchange Rates and International Currency Exposures". American Economic Review, American Economic Association, vol. 100(1), pp. 518-40, March.

Lane, P. R. and G. M. Milesi-Ferretti. 2007. "The External Wealth of Nations Mark II: Revised and Extended Estimates of Foreign Assets and Liabilities, 1970-2004”. Journal of International Economics, 73(2): 223-50.

Lim, C., F. Columba, A. Costa, P. Kongsamut, A. Otani, M. Saiyid, T. Wezel and X. Wu., 2011. "Macroprudential Policy: What Instruments and How to Use Them? Lessons from Country Experiences". IMF Working Paper WP/11/238.

Lim, C., I. Krznar, F. Lipinsky, A. Otani and X. Wu, 2013. "The Macroprudential Framework: Policy Responsiveness and Institutional Arrangements". IMF Working Paper WP/13/166.

Lo Duca, M., G. Nicoletti and A. Vidal Martinez, 2014. Global Corporate Bond Issuance - What Role for US Quantitative Easing?. ECB Working Paper 1649, European Central Bank, Frankfurt.

McGuire, P. and N. Tarashev, 2008. "Bank Health and Lending to Emerging Markets". BIS Quarterly Review, pp. 67-80.

Milesi-Ferretti, G. M. and C. Tille (2011): "The Great Retrenchment: International Capital Flows during the Global Financial Crisis". Economic Policy, April, 66:285-342.

Miranda-Agrippino, S. and H. Rey, 2013. "Funding Flows and Credit in Carry Trade Economies". RBA Annual Conference Volume, in: Alexandra Heath \& Matthew Lilley \& Mark Manning (ed.), Liquidity and Funding Markets Reserve Bank of Australia.

OECD (2016), OECD Economic Outlook, Interim Report September 2016, OECD Publishing, Paris. http://dx.doi.org/10.1787/eco outlook-v2016-sup2-en. 
OECD (2015), OECD Economic Outlook, Interim Report September 2015, OECD Publishing, Paris. http://dx.doi.org/10.1787/eco_outlook-v2015-sup1-en.

Ongena, S., A. Popov, G. F. Udell, 2013. "When the cat's away the mice will play: Does regulation at home act bank risk-taking abroad?". Journal of Financial Economics 108 (3),727-750.

Ostry, J.D., A. R. Ghosh, K. Habermeier, M. Chamon, M. S. Qureshi and D. B.S. Reinhardt, 2010. "Capital Inflows: The Role of Controls". IMF Staff Position Note, SPN/10/04.

Ostry, J.D., A. R. Ghosh, K. Habermeier, L. Laeven,M. Chamon, M. S. Qureshi, S. Mahvash, A. Kokenyne, 2011. "Managing Capital Inflows: What Tools to Use?". IMF Staff Discussion Notes 11/06, International Monetary Fund.

Pasricha, G., M. Falagiarda, M. Bijsterbosch, and J. Aizenman, 2015. "Domestic and Multilateral Effects of Capital Controls in Emerging Markets". NBER Working Paper Series, No. 20822.

Prasad, E., 2014. "Managing Capital Flow Volatility". BIS Papers chapters, in: Bank for International Settlements (ed.), Long-term finance: can emerging capital markets help?, volume 75, pp. 13-17 Bank for International Settlements.

Prat, S., 2007. "The Relevance of Currency Mismatch Indicators: an Analysis through Determinants of Emerging Market Spreads". Economie Internationale, 111: 101-122.

Ranciere, R., A. Tornell and A. Vamvakidis, 2010. "A New Index of Currency Mismatch and Systemic Risk". IMF Working Paper WP/10/263.

Reinhart, C. M., K. S. Rogoff and M. A. Savastano, 2014. Addicted to Dollars. Annals of Economics and Finance, Society for AEF, vol. 15(1), pp. 1-50, May.

Reinhardt, D. and R. Sowerbutts, 2015. Regulatory arbitrage in action: evidence from banking flows and macroprudential policy". Bank of England Staff Working Paper No. 546.

Rey, H. 2015. "Dilemma not Trilemma: The global Financial Cycle and Monetary Policy Independence". NBER Working Papers 21162, National Bureau of Economic Research, Inc.

Qureshi, M.S., J. D. Ostry, A. R. Ghosh and M. Chamon, 2011. "Managing Capital Inflows: The Role of Capital Controls and Prudential Policies”. NBER Working Paper Series, No 17363.

Sarno, L., I. Tsiakas and B. Ulloa, 2015. "What Drives International Portfolio Flows?". Working Paper Series 15-16, The Rimini Centre for Economic Analysis.

Schindler, M., 2009. "Measuring Financial Integration: A New Dataset”. IMF Staff Papers 56(1):222-38.

Shim, I., B. Bogdanova, J. Shek and A. Subelyte, 2013. Database for Policy Actions on Housing Markets. BIS Quarterly Reviw, September, 83-95.

Shin, H. S. 2012. "Adapting Macroprudential Policies to Global Liquidity Conditions". Journal Economía Chilena (The Chilean Economy), Central Bank of Chile, vol. 15(2), pp. 33-65, August.

Shin, H. S., 2013. "The second phase of global liquidity and its impact on emerging economies".

World Bank. 2015. “The Coming U.S. Interest Rate Tightening Cycle: Smooth Sailing or Stormy Waters?" Policy Research Note. September 2015 PRN/15/02.

Zhang, L. and E. Zoli, 2014. "Leaning Against the Wind: Macroprudential Policy in Asia". IMF Working Paper WP/14/22. 


\section{ANNEX 1 - COUNTRY COVERAGE}

Table 1. Country Coverage

\begin{tabular}{|c|c|c|}
\hline Country & OECD - Member & G20 - Member \\
\hline \hline Australia & Yes & Yes \\
\hline Brazil & No & Yes \\
\hline Canada & Yes & No \\
\hline Chile & Yes & No \\
\hline Colombia & No & No \\
\hline Hungary & Yes & Yes \\
\hline India & No & No \\
\hline Indonesia & No & Yes \\
\hline Israel & Yes & No \\
\hline Korea, Rep. & Yes & Yes \\
\hline Malaysia & No & No \\
\hline Mexico & Yes & No \\
\hline Paraguay & No & No \\
\hline Romania & No & No \\
\hline Singapore & No & No \\
\hline Slovenia & Yes & Yes \\
\hline Thailand & No & \\
\hline Turkey & Yes & Yes \\
\hline
\end{tabular}




\section{ANNEX 2 - LIST OF ACRONYMS}

Table 2. List of Acronyms

\begin{tabular}{|c|c|}
\hline AEs & Advanced Economies \\
\hline AREAER & Annual Report on Exchange Arrangement and Exchange Restrictions \\
\hline ATFC & Advisory Task Force on the Codes \\
\hline BIS & Bank for International Settlements \\
\hline BoE & Bank of England \\
\hline BoJ & Bank of Japan \\
\hline CBCFMs & Currency-Based Capital Flow Management measures \\
\hline CBMs & Currency-Based Measures \\
\hline CFMs & Capital Flow Management measures \\
\hline CPI & Consumer Price Index \\
\hline DP & Dynamic Provisioning \\
\hline DRR & Differentiated Reserve Requirements \\
\hline DTI & Debt-To-Income \\
\hline $\mathrm{ECB}$ & European Central Bank \\
\hline EMEs & Emerging Market Economies \\
\hline ERR & Exchange Rate Regime \\
\hline FSB & Financial Stability Board \\
\hline FSI & Financial Soundness Indicator \\
\hline $\mathrm{FX}$ & Foreign Exchange \\
\hline GFD & Global Financial Development \\
\hline GFS & Government Finance Statistics \\
\hline IDS & International Debt Statistics \\
\hline IMF & International Monetary Fund \\
\hline IFS & International Financial Statistics \\
\hline LTV & Loan-To-Value \\
\hline MPMs & Macro-Prudential Measures \\
\hline OECD & Organization for Economic Co-operation and Development \\
\hline $\mathrm{QE}$ & Quantitative Easing \\
\hline QEDS & Quarterly External Debt Statistics \\
\hline RR & Reserve Requirements \\
\hline VIX & Volatility Index \\
\hline WEO & World Economic Outlook \\
\hline
\end{tabular}




\section{ANNEX 3 - DATA DESCRIPTION AND SOURCES}

Table 3. Data sources

\begin{tabular}{|c|c|}
\hline Variable & ource, original frequency and description \\
\hline External debt & $\begin{array}{l}\text { The sector breakdown of the external debt comes from the World Bank's } \\
\text { QEDS database (quarterly data from 2000Q1 to 2014Q4). We collect data } \\
\text { on the external debt of deposit-taking corporations, defined as commercial } \\
\text { banks, savings banks (including trustee savings banks and savings and } \\
\text { loan associations), credit unions or cooperatives, traveller's check } \\
\text { companies, and specialized banks or other financial institutions if they } \\
\text { take deposits or issue close substitutes for deposits. The QEDS database } \\
\text { also provides a breakdown of external debt by maturity (short-term and } \\
\text { long term debt) as well as debt instrument (debt securities, loans and } \\
\text { deposits). }\end{array}$ \\
\hline Total FX Liabilities & $\begin{array}{l}\text { Total liabilities of BIS reporting banks or of other deposit taking } \\
\text { corporations (excluding the Central Bank), denominated in foreign } \\
\text { currency, to residents and non-residents. Original frequency: quarterly } \\
\text { data. Source: BIS Tables 2A-2D and 4A-4B, National Central Banks and } \\
\text { FSI. }\end{array}$ \\
\hline Capital Controls & $\begin{array}{l}\text { Annual indices of capital control restrictions. Source: Fernandez et al. } \\
\text { (2015). Original frequency: annual data. We include as control variables } \\
\text { an overall index of restrictions, an index on restrictions on inflows, and } \\
\text { one on restrictions on outflows. }\end{array}$ \\
\hline MPPs & $\begin{array}{l}\text { Source: IMF survey (2010). We include the following variables: i) LTV, } \\
\text { ii) DTI, iii) caps on foreign currency lending, iv) ceiling on credit, v) } \\
\text { reserve requirements, vi) counter-cyclical capital requirement, vii) } \\
\text { dynamic provisioning and viii) restriction on profit distribution. Data are } \\
\text { available for } 52 \text { countries. Original Frequency: quarterly data (only } \\
\text { available through 2010). }\end{array}$ \\
\hline CB-CFMs & $\begin{array}{l}\text { We exploit a newly built OECD dataset (De Crescenzio et al. 2015) on } \\
\text { currency-based restrictions targeting banks. Original frequency: quarterly } \\
\text { data. }\end{array}$ \\
\hline QE & $\begin{array}{l}\text { Size of balance sheet of European Central Bank, US Fed, Bank of } \\
\text { England, Bank of Japan. Original frequency: quarterly data. Source: IFS } \\
\text { and Bank of England Statistics. }\end{array}$ \\
\hline $\begin{array}{l}\text { Monetary policy- } \\
\text { related interest rate of } \\
\text { relevant economies }\end{array}$ & $\begin{array}{l}\text { Monetary policy-related interest rate of the Euro area, United States, } \\
\text { United Kingdom, Japan and Canada. Original frequency: quarterly data. } \\
\text { Source: IFS. }\end{array}$ \\
\hline VIX Index & $\begin{array}{l}\text { We have data on the value of the index at the opening and closing of the } \\
\text { market as well as the highest and lowest daily values. Original frequency: } \\
\text { daily data. Source: http://www.cboe.com/micro/vix/historical.aspx. }\end{array}$ \\
\hline Global financial crisis & Dummy variable that takes value one from 2007Q3 to 2011Q3. \\
\hline $\begin{array}{l}\text { Nominal GDP growth } \\
\text { rate }\end{array}$ & $\begin{array}{l}\text { Nominal gross domestic product, growth rate. Original frequency: } \\
\text { quarterly data. Source: IFS and WEO. }\end{array}$ \\
\hline $\begin{array}{l}\text { Monetary policy- } \\
\text { related interest rate }\end{array}$ & $\begin{array}{l}\text { Monetary policy-related interest rate of a given country. Original } \\
\text { frequency: quarterly data. Source: IFS. }\end{array}$ \\
\hline Inflation & $\begin{array}{l}\text { CPI, percent change over corresponding period of previous year. Original } \\
\text { frequency: quarterly data. Source: IFS and WEO. }\end{array}$ \\
\hline
\end{tabular}




\begin{tabular}{|l|l|}
\hline Total public deficit & $\begin{array}{l}\text { Net borrowing (-)/lending (+) of the central government expressed in } \\
\text { national currency, units. Original frequency: quarterly data. Source: } \\
\text { OECD Statistics, GFS and WEO. }\end{array}$ \\
\hline International reserves & $\begin{array}{l}\text { International reserves in foreign exchange. Original frequency: quarterly } \\
\text { data. Source: IFS. }\end{array}$ \\
\hline Exchange rate & $\begin{array}{l}\text { Nominal, US Dollar per National Currency. Original frequency: quarterly } \\
\text { data. Source: IFS. }\end{array}$ \\
\hline $\begin{array}{l}\text { Financial development } \\
\text { indicator }\end{array}$ & $\begin{array}{l}\text { We include data on financial institutions' access, efficiency, depth and } \\
\text { stability. Original Frequency: annual data, quarterly frequency through } \\
\text { linear interpolation. Source: GFD database; latest version: July 2016. }\end{array}$ \\
\hline Bank leverage & $\begin{array}{l}\text { Bank credit to bank deposits (\%); Original frequency: annual data (only } \\
\text { available through 2011). The variable is linearly interpolated over time. } \\
\text { Source: GFD database; latest version: July 2016. }\end{array}$ \\
\hline Banking crisis & $\begin{array}{l}\text { Dummy variable that takes value 1 in case of a banking crisis in a given } \\
\text { country and quarter. Original frequency: annual data. Source: GFD } \\
\text { database; latest version: July 2016. }\end{array}$ \\
\hline Real Estate Price Index & $\begin{array}{l}\text { We include both the real and nominal residential property price yoy } \\
\text { growth rate as well as an index that takes 2010 as base year. Original } \\
\text { frequency: quarterly data. Source: BIS. }\end{array}$ \\
\hline
\end{tabular}

Data on gross external debt are in millions of local currency and cover the entire economy. Data are by maturity, on an original and remaining maturity basis, and by instruments for the following prescribed components: debt securities, loans, currency and deposits, trade credit and advances, other debt instruments, defined in the context of the functional categories in the IMF Balance of Payment Manual.

Currency and deposits consists of notes and coin and both transferable and other deposits. Transferable deposits consist of deposits that are (1) exchangeable on demand at par and without penalty or restriction, and (2) directly usable for making payments by check, giro order, direct debit/credit, or other direct payment facility. Other deposits comprise all claims represented by evidence of deposit-for example, savings and fixed-term deposits; sight deposits that permit immediate cash withdrawals but not direct thirdparty transfers; and shares that are legally (or practically) redeemable on demand or on short notice in savings and loan associations, credit unions, building societies, etc.

Loans include those financial assets created through the direct lending of funds by a creditor (lender) to a debtor (borrower) through an arrangement in which the lender either receives no security evidencing the transactions or receives a non-negotiable document or instrument. Collateral, in the form of either a financial asset (such as a security) or nonfinancial asset (such as land or a building) may be provided under a loan transaction, although it is not an essential feature. In the gross external debt position, loans include use of IMF credit and loans from the IMF. If a loan becomes tradable and is, or has been, traded in the secondary market, the loan should be reclassified as a debt security.

Debt securities include all securities other than shares and Trade credits and advances position includes supplier credits (DMFAS source) and short term commercial liabilities.

The criterion used for determining whether a liability is a debt instrument or not is the future requirement to make payments - principal and/or interest; therefore, it excludes equity capital, financial derivatives, open credit lines and other contingent liabilities." The stock of the liabilities is recorded at face value and market price (Quarterly External Debt Statistics tables). All external debt is recorded on a gross basis, separate from any related asset component. 
The Quarterly External Debt Statistics (QESD) classifies the following institutional sectors consistent with the 1993 SNA: General Government, Central Bank, Deposit-Taking Corporations except the Central Bank, and other sectors (nonbank financial corporations, nonfinancial corporations, and households and nonprofit institutions serving households subsectors). Deposit-taking corporations define the banking sector. More precisely, it includes all resident units engaging in financial intermediation as a principal activity and having liabilities in the form of deposits payable on demand, transferable by check, or otherwise used for making payments, or having liabilities in the form of deposits that may not be readily transferable, such as short-term certificates of deposit, but that are close substitutes for deposits and are included in measures of money broadly defined. Thus, in addition to commercial banks, the banking sector encompasses institutions such as savings banks, savings and loan associations, credit unions or cooperatives, and building societies. Post office savings banks or other government-controlled savings banks are also included if they are institutional units separate from the government. 
ANNEX 4 - DESCRIPTIVE STATISTICS

Table 4. Summary statistics of the ratio of short-term to total external debt

\begin{tabular}{|l|ccc|ccc|}
\cline { 2 - 7 } \multicolumn{1}{c|}{} & \multicolumn{3}{c}{ Pre-crisis } & \multicolumn{3}{c|}{ Post-crisis } \\
\cline { 2 - 7 } \multicolumn{1}{c|}{} & Obs. & Mean & St. Dev. & Obs. & Mean & St. Dev. \\
\hline Australia & 14 & 48.95 & 1.07 & 22 & 45.68 & 2.09 \\
\hline Brazil & 14 & 47.44 & 6.95 & 22 & 95.99 & 2.56 \\
\hline Canada & 14 & 99.32 & 0.18 & 22 & 34.72 & 6.60 \\
\hline Chile & 14 & 15.90 & 7.82 & 22 & 48.22 & 10.46 \\
\hline Colombia & 14 & 66.68 & 5.98 & 22 & 34.78 & 4.18 \\
\hline Hungary & 14 & 32.29 & 2.45 & 22 & 85.68 & 4.80 \\
\hline Indonesia & 14 & 64.21 & 9.85 & 22 & 2.23 & 1.34 \\
\hline Israel & 14 & 84.64 & 2.01 & 22 & 56.40 & 8.54 \\
\hline India & 10 & 1.36 & 1.40 & 22 & 52.42 & 13.58 \\
\hline Korea, Rep. & 14 & 67.65 & 3.74 & 8 & 86.57 & 0.96 \\
\hline Mexico & 14 & 36.44 & 9.86 & 7 & 98.58 & 0.47 \\
\hline Malaysia & & & 22 & 30.58 & 4.99 \\
\hline Paraguay & 14 & 81.09 & 10.95 & 22 & 92.71 & 0.75 \\
\hline Romania & & & 22 & 12.78 & 1.68 \\
\hline Singapore & 14 & 95.47 & 0.73 & 22 & 70.41 & 8.44 \\
\hline Slovenia & 14 & 5.86 & 3.36 & 22 & 55.49 & 7.04 \\
\hline Thailand & 14 & 50.89 & 7.19 & 367 & 53.26 \\
\hline Turkey & 14 & 49.84 & 12.67 & 28.99 & & 27.50 \\
\hline Total sample & 221 & 53.86 & & & \\
\hline
\end{tabular}

Source: World Bank's Quarterly External Debt Statistics database. 
Table 5. Rate of growth of total and short-term external debt

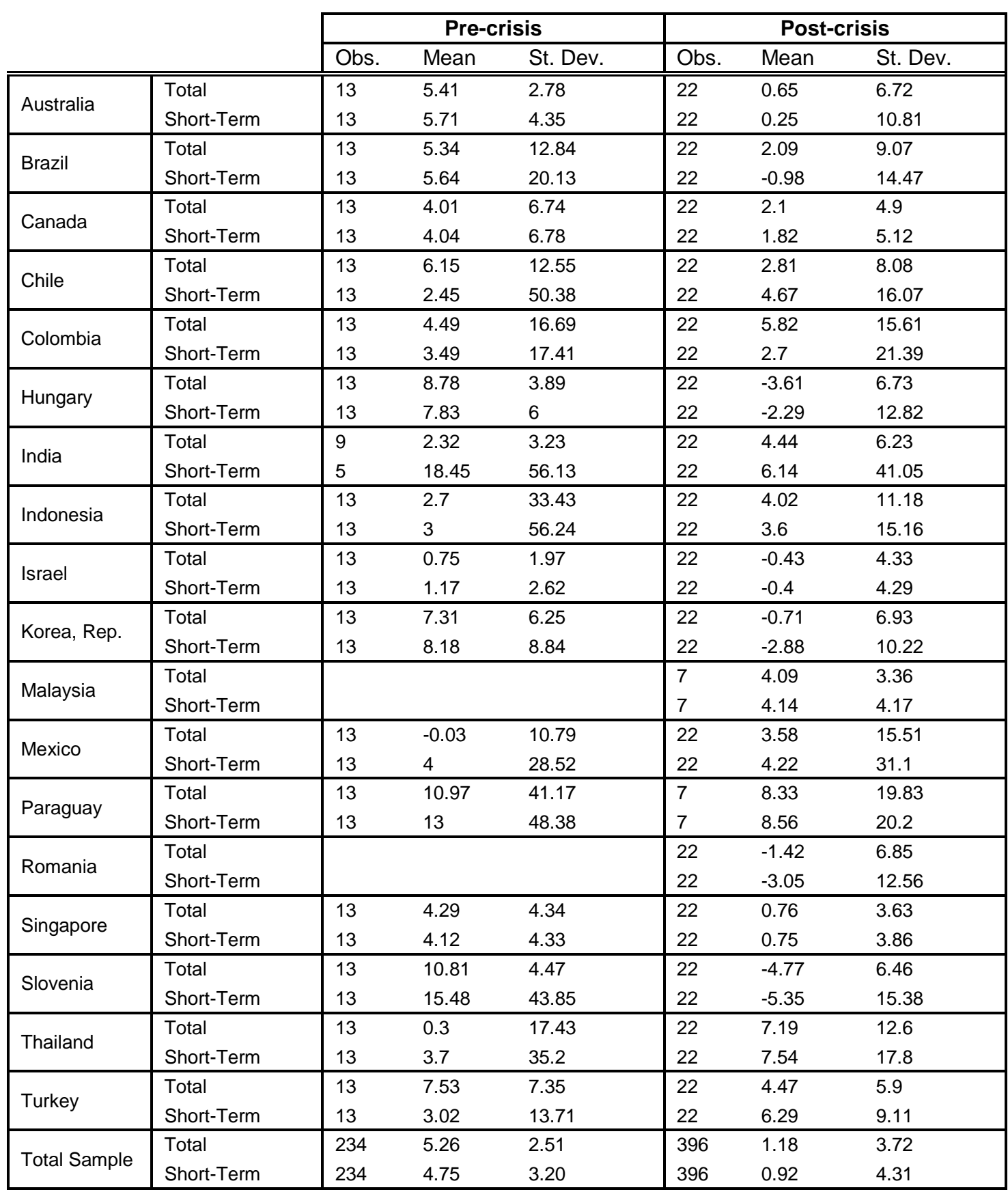

Source: World Bank's Quarterly External Debt Statistics database. 
Table 6. External loans, securities and deposits as a share of total external debt - Pre-crisis period

\begin{tabular}{|c|c|c|c|c|c|c|c|}
\hline & \multirow[b]{3}{*}{ Obs. } & \multirow{2}{*}{\multicolumn{2}{|c|}{ Loans }} & & & & \\
\hline & & & & \multicolumn{2}{|c|}{ Securities } & \multicolumn{2}{|c|}{ Deposits } \\
\hline & & Mean & St. Dev. & Mean & St. Dev. & Mean & St. Dev. \\
\hline Australia & 14 & 12.05 & 2.18 & 70.97 & 2.83 & 16.18 & 1.48 \\
\hline Brazil & 14 & 59.64 & 3.33 & 35.53 & 2.94 & 1.29 & 0.30 \\
\hline Canada & 14 & 0.00 & 0.00 & 1.88 & 0.38 & 98.12 & 0.38 \\
\hline Chile & 14 & 82.52 & 3.05 & 16.36 & 3.17 & 1.26 & 0.62 \\
\hline Colombia & 14 & 91.62 & 5.93 & 8.38 & 5.93 & & \\
\hline Hungary & 14 & 35.97 & 5.40 & 21.73 & 4.21 & 41.99 & 2.24 \\
\hline Indonesia & 14 & 20.40 & 7.77 & 36.97 & 9.29 & 23.45 & 7.76 \\
\hline Israel & 14 & 0.00 & 0.00 & 0.00 & 0.00 & 100.00 & 0.00 \\
\hline India & 10 & 2.96 & 0.81 & 1.26 & 0.10 & 95.77 & 0.74 \\
\hline Korea, Rep. & 14 & 68.26 & 3.59 & 26.72 & 2.73 & 4.00 & 0.85 \\
\hline Mexico & 14 & 73.52 & 4.93 & 14.56 & 1.21 & 10.71 & 3.80 \\
\hline \multicolumn{8}{|l|}{ Malaysia } \\
\hline Paraguay & 14 & 21.39 & 12.64 & 0.00 & 0.00 & 44.89 & 25.51 \\
\hline Romania & & & . & & . & & . \\
\hline Singapore & 14 & 0.00 & 0.00 & 0.73 & 0.20 & 94.19 & 0.53 \\
\hline Slovenia & 14 & 68.36 & 2.46 & 3.06 & 0.73 & 28.02 & 1.74 \\
\hline Thailand & 14 & 71.82 & 16.32 & 6.06 & 1.19 & 15.57 & 4.40 \\
\hline Turkey & 14 & 76.42 & 2.53 & 0.00 & 0.00 & 23.61 & 2.53 \\
\hline Total sample & 221 & 43.51 & 33.48 & 15.46 & 19.28 & 36.47 & 36.82 \\
\hline
\end{tabular}

Source: World Bank's Quarterly External Debt Statistics database. 
Table 7. External loans, securities and deposits as a share of total external debt - Post-crisis period

\begin{tabular}{|c|c|c|c|c|c|c|c|}
\hline & \multirow[b]{2}{*}{ Obs. } & \multicolumn{2}{|c|}{ Loans } & \multicolumn{2}{|c|}{ Securities } & \multicolumn{2}{|c|}{ Deposits } \\
\hline & & Mean & St. Dev. & Mean & St. Dev. & Mean & St. Dev. \\
\hline Australia & 22 & 6.01 & 9.03 & 65.40 & 2.19 & 19.25 & 3.79 \\
\hline Brazil & 22 & 65.24 & 2.10 & 33.10 & 2.33 & 0.62 & 0.21 \\
\hline Canada & 22 & 0.00 & 0.00 & 5.21 & 2.97 & 97.68 & 1.46 \\
\hline Chile & 22 & 71.54 & 10.45 & 25.17 & 9.79 & 3.28 & 0.98 \\
\hline Colombia & 22 & 69.40 & 13.47 & 30.60 & 13.47 & & \\
\hline Hungary & 22 & 33.86 & 2.90 & 14.00 & 4.17 & 51.99 & 3.22 \\
\hline Indonesia & 22 & 26.03 & 4.84 & 29.67 & 5.53 & 36.45 & 5.18 \\
\hline Israel & 22 & 0.00 & 0.00 & 0.00 & 0.00 & 100.00 & 0.00 \\
\hline India & 22 & 14.82 & 8.85 & 0.80 & 0.36 & 84.38 & 8.73 \\
\hline Korea, Rep. & 22 & 62.88 & 4.86 & 29.67 & 3.04 & 6.25 & 2.03 \\
\hline Mexico & 22 & 65.25 & 5.57 & 14.43 & 3.34 & 15.33 & 4.26 \\
\hline Malaysia & 7 & 53.63 & 3.33 & 13.37 & 0.93 & 31.88 & 2.71 \\
\hline Paraguay & 7 & 3.83 & 1.03 & 0.00 & 0.00 & 74.13 & 7.57 \\
\hline Romania & 22 & 35.58 & 11.66 & 0.91 & 0.57 & 62.28 & 11.88 \\
\hline Singapore & 22 & 0.00 & 0.00 & 0.43 & 0.21 & 91.95 & 0.71 \\
\hline Slovenia & 22 & 62.11 & 5.40 & 12.37 & 5.66 & 25.29 & 1.72 \\
\hline Thailand & 22 & 84.96 & 15.93 & 2.44 & 1.69 & 13.60 & 5.15 \\
\hline Turkey & 22 & 61.46 & 5.54 & 4.13 & 4.60 & 34.43 & 4.11 \\
\hline Total sample & 366 & 40.72 & 29.95 & 16.38 & 17.88 & 38.76 & 34.39 \\
\hline
\end{tabular}

Source: World Bank's Quarterly External Debt Statistics database. 
Table 8. Rate of growth of external securities, loans and deposits

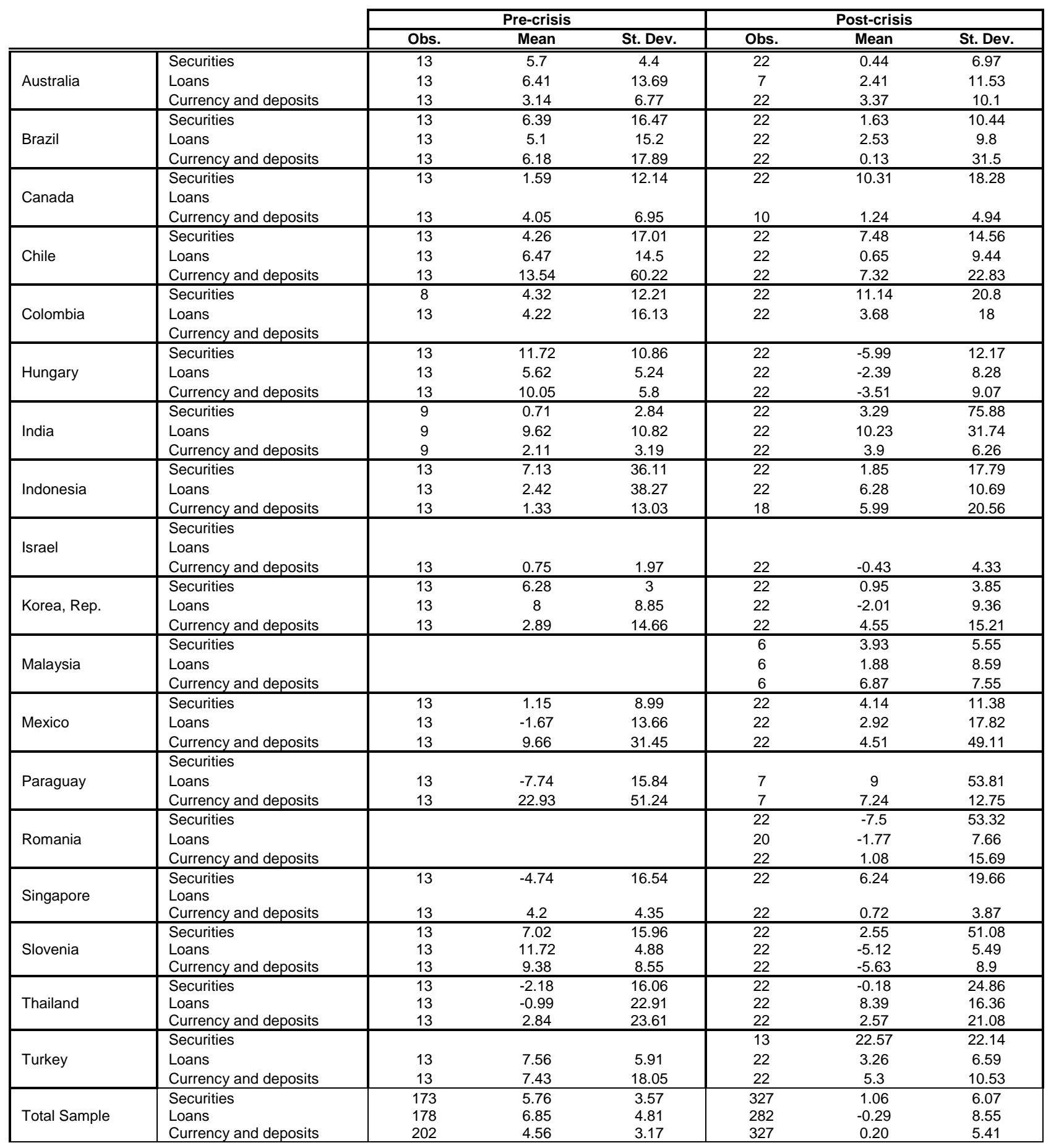

Source: World Bank's Quarterly External Debt Statistics database. 
Table 9. Rate of growth of FX liabilities

\begin{tabular}{|c|c|c|c|c|c|c|}
\hline & \multicolumn{3}{|c|}{ Pre-crisis } & \multicolumn{3}{|c|}{ Post-crisis } \\
\hline & Obs. & Mean & St. Dev. & Obs. & Mean & St. Dev. \\
\hline Australia & 13 & 5.81 & 4.2 & 22 & 0.65 & 5.41 \\
\hline Brazil & 13 & 2.67 & 14.8 & 22 & 4.28 & 10.43 \\
\hline Canada & 13 & 5.14 & 6.16 & 22 & 1.15 & 5.61 \\
\hline Chile & 13 & 7.11 & 9.56 & 22 & 1.85 & 7.95 \\
\hline Colombia & 13 & 6.47 & 15.4 & 20 & -3.34 & 162.16 \\
\hline Hungary & 13 & 6.87 & 3.88 & 22 & -1.14 & 6.48 \\
\hline Indonesia & & & & 12 & 3.86 & 3.98 \\
\hline Israel & 13 & -2.34 & 11.58 & 22 & 2.02 & 120.59 \\
\hline India & 13 & 2.56 & 6.76 & 22 & 2.07 & 9.11 \\
\hline Korea, Rep. & 13 & 7.27 & 12.8 & 22 & -0.93 & 10.35 \\
\hline Mexico & 13 & 4.45 & 27.59 & 22 & 4.51 & 14.81 \\
\hline Malaysia & 2 & 7.17 & 6.56 & 22 & 2.49 & 4.88 \\
\hline Paraguay & & & & & & \\
\hline Romania & & & & & & \\
\hline Singapore & 13 & 3.84 & 4.08 & 22 & 1.31 & 4.78 \\
\hline Slovenia & & & & & & \\
\hline Thailand & & & & & & \\
\hline Turkey & 10 & 4.5 & 7.18 & 22 & 5.2 & 4.96 \\
\hline Total sample & 155 & 4.56 & 12.07 & 311 & 1.62 & 51.52 \\
\hline
\end{tabular}

Source: BIS Locational Banking Statistics. 


\section{ANNEX 5 - REGRESSION TABLES}

Table 10. The impact of currency-based measures on external debt

\begin{tabular}{|c|c|c|c|c|c|c|c|}
\hline & $(1)$ & $(2)$ & (3) & $(4)$ & $(5)$ & (6) & $(7)$ \\
\hline VARIABLES & $\mathrm{RE}$ & RE & RE & RE & RE & $\mathrm{RE}$ & $\mathrm{RE}$ \\
\hline \multirow[t]{2}{*}{ CBCFM $(-1)$} & -0.010 & -0.009 & $-0.016^{\star}$ & -0.007 & -0.010 & -0.010 & -0.010 \\
\hline & 0.01 & 0.01 & 0.01 & 0.01 & 0.01 & 0.01 & 0.01 \\
\hline \multirow[t]{2}{*}{ fc } & $0.027^{\star \star *}$ & $0.017^{\star *}$ & & & & & \\
\hline & 0.01 & 0.01 & & & & & \\
\hline \multirow[t]{2}{*}{ VIX } & $-0.035^{\star * *}$ & $-0.028^{* * *}$ & $-0.027^{\star *}$ & $-0.036^{* * *}$ & $-0.030^{* * *}$ & $-0.025^{* * *}$ & $-0.021^{\star *}$ \\
\hline & 0.01 & 0.01 & 0.01 & 0.01 & 0.01 & 0.01 & 0.01 \\
\hline \multirow[t]{2}{*}{ GDP (growth rate) } & $0.069^{\star * *}$ & $0.081^{* * *}$ & $0.065^{\star * *}$ & $0.089^{* * *}$ & 0.178 & $0.056^{\star *}$ & $0.092^{\star * *}$ \\
\hline & 0.02 & 0.02 & 0.02 & 0.02 & 0.15 & 0.03 & 0.02 \\
\hline \multirow[t]{2}{*}{$\Delta$ Exch. Rate } & $0.363^{\star \star *}$ & $0.373^{\star * *}$ & $0.310^{\star * *}$ & $0.394^{\star \star \star}$ & $0.329^{* * *}$ & $0.396^{* * *}$ & $0.403^{* * *}$ \\
\hline & 0.07 & 0.07 & 0.07 & 0.08 & 0.06 & 0.06 & 0.07 \\
\hline \multirow[t]{2}{*}{$\begin{array}{l}\Delta \text { Bank Credit / Bank } \\
\text { Deposits }\end{array}$} & & $0.008^{* * *}$ & $0.008^{* * *}$ & $0.007^{* *}$ & $0.006^{\star *}$ & $0.008^{* * *}$ & $0.011^{* * *}$ \\
\hline & & 0.00 & 0.00 & 0.00 & 0.00 & 0.00 & 0.00 \\
\hline \multirow[t]{2}{*}{ Banking Crisis dummy } & & & $-0.030^{* * *}$ & & & & \\
\hline & & & 0.01 & & & & \\
\hline \multirow[t]{2}{*}{ Log Balance Sheet } & & & & -0.038 & & & \\
\hline & & & & 0.03 & & & \\
\hline \multirow[t]{2}{*}{$\Delta$ Spread US } & & & & & 0.001 & & \\
\hline & & & & & 0.00 & & \\
\hline \multirow[t]{2}{*}{$\Delta \mathrm{FX}$ Intern. Reserves } & & & & & & 0.098 & \\
\hline & & & & & & 0.08 & \\
\hline \multirow[t]{2}{*}{$\Delta$ Fin. System Deposits } & & & & & & & $0.011^{\star * *}$ \\
\hline & & & & & & & 0.00 \\
\hline \multirow[t]{2}{*}{ Constant } & $0.123^{\star \star \star}$ & $0.104^{* * *}$ & $0.116^{* * *}$ & 1.377 & $0.118^{* * *}$ & $0.100^{* * *}$ & $0.086^{\star * *}$ \\
\hline & 0.03 & 0.03 & 0.04 & 0.97 & 0.03 & 0.03 & 0.03 \\
\hline Observations & 555 & 523 & 407 & 462 & 363 & 523 & 472 \\
\hline Number of countries & 18 & 18 & 17 & 18 & 13 & 18 & 18 \\
\hline
\end{tabular}

Note: This table shows panel regressions where the dependent variable is quarterly aggregate rate of growth of external debt in the banking sector of country $i$ at time t. For each independent variable, the first row shows the coefficient and the second row the standard error. $* * * * *, *$ and + indicate significance at the $1 \%, 5 \%, 10 \%$ and $15 \%$ level, respectively. 
Table 11. The impact of currency-based measures on external debt - controlling for MPMs

\begin{tabular}{|c|c|c|c|c|c|}
\hline & (1) & (2) & (3) & (4) & (5) \\
\hline VARIABLES & RE & RE & $\mathrm{RE}$ & $\mathrm{RE}$ & $\mathrm{RE}$ \\
\hline \multirow[t]{2}{*}{ CBCFM $(-1)$} & $-0.023^{\star \star *}$ & $-0.022^{\star * *}$ & $-0.022^{* *}$ & $-0.023^{\star *}$ & $-0.023^{\star * *}$ \\
\hline & 0.01 & 0.01 & 0.01 & 0.01 & 0.01 \\
\hline \multirow[t]{2}{*}{ fc } & 0.005 & 0.004 & 0.006 & 0.004 & 0.005 \\
\hline & 0.01 & 0.01 & 0.01 & 0.01 & 0.01 \\
\hline \multirow[t]{2}{*}{ VIX } & $-0.038^{* *}$ & $-0.038^{* *}$ & $-0.039^{* *}$ & $-0.038^{\star *}$ & $-0.038^{* *}$ \\
\hline & 0.02 & 0.02 & 0.02 & 0.02 & 0.02 \\
\hline \multirow[t]{2}{*}{ GDP (growth rate) } & 0.053 & 0.054 & 0.042 & 0.053 & 0.053 \\
\hline & 0.06 & 0.06 & 0.06 & 0.06 & 0.06 \\
\hline \multirow[t]{2}{*}{$\Delta$ Exch. Rate } & $0.281^{\star * *}$ & $0.276^{* * *}$ & $0.294^{* * *}$ & $0.271^{* * *}$ & $0.284^{\star \star *}$ \\
\hline & 0.10 & 0.10 & 0.09 & 0.10 & 0.10 \\
\hline \multirow[t]{2}{*}{ LTV } & & 0.007 & & & \\
\hline & & 0.01 & & & \\
\hline \multirow[t]{2}{*}{ DTI } & & & $0.122^{*}$ & & \\
\hline & & & 0.06 & & \\
\hline \multirow[t]{2}{*}{ DP } & & & & $0.031^{* *}$ & \\
\hline & & & & 0.01 & \\
\hline \multirow[t]{2}{*}{$\mathrm{RR}$} & & & & & $-0.024^{* * *}$ \\
\hline & & & & & 0.00 \\
\hline \multirow[t]{2}{*}{ Constant } & $0.148^{\star \star *}$ & $0.144^{* * *}$ & $0.147^{* * *}$ & $0.148^{\star * \star}$ & $0.148^{\star * *}$ \\
\hline & 0.05 & 0.05 & 0.05 & 0.05 & 0.05 \\
\hline Observations & 293 & 293 & 293 & 293 & 293 \\
\hline Number of countries & 14 & 14 & 14 & 14 & 14 \\
\hline
\end{tabular}

Note: This table shows panel regressions where the dependent variable is quarterly aggregate rate of growth of external debt in the banking sector of country $i$ at time $t$. For each independent variable, the first row shows the coefficient and the second row the standard error. $* * *, * * *$ and + indicate significance at the $1 \%, 5 \%, 10 \%$ and $15 \%$ level, respectively. 
Table 12. The impact of currency-based measures on short-term external debt

\begin{tabular}{|c|c|c|c|c|c|c|c|}
\hline & (1) & $(2)$ & (3) & (4) & (5) & (6) & (7) \\
\hline VARIABLES & $\mathrm{RE}$ & RE & $\mathrm{RE}$ & $\mathrm{RE}$ & $\mathrm{RE}$ & $\mathrm{RE}$ & $\mathrm{RE}$ \\
\hline \multirow[t]{2}{*}{ CBCFM (-1) } & $-0.026^{\star * *}$ & $-0.023^{* *}$ & $-0.023+$ & $-0.027^{\star *}$ & $-0.027^{\star *}$ & $-0.025^{\star * *}$ & $-0.027^{\star *}$ \\
\hline & 0.01 & 0.01 & 0.01 & 0.01 & 0.01 & 0.01 & 0.01 \\
\hline \multirow[t]{2}{*}{ fc } & $0.036^{* * *}$ & $0.025^{\star}$ & & & & & \\
\hline & 0.01 & 0.01 & & & & & \\
\hline \multirow[t]{2}{*}{ VIX } & -0.030 & -0.017 & -0.014 & -0.028 & 0.003 & -0.012 & $-0.029^{\star *}$ \\
\hline & 0.02 & 0.02 & 0.03 & 0.02 & 0.03 & 0.02 & 0.01 \\
\hline \multirow[t]{2}{*}{ GDP (growth rate) } & $0.119^{* * *}$ & $0.157^{\star * *}$ & $0.135^{\star * *}$ & $0.170^{* * *}$ & 0.273 & $0.130^{* * *}$ & $0.168^{\star \star \star}$ \\
\hline & 0.03 & 0.04 & 0.03 & 0.04 & 0.23 & 0.04 & 0.04 \\
\hline \multirow[t]{2}{*}{$\Delta$ Exch. Rate } & $0.664^{* * *}$ & $0.773^{\star \star *}$ & $0.684^{* * *}$ & $0.794^{\star * *}$ & $0.761^{\star * *}$ & $0.797^{\star \star *}$ & $0.799^{\star \star *}$ \\
\hline & 0.12 & 0.15 & 0.12 & 0.16 & 0.11 & 0.15 & 0.15 \\
\hline \multirow[t]{2}{*}{$\begin{array}{l}\Delta \text { Bank Credit / Bank } \\
\text { Deposits }\end{array}$} & & $0.013^{\star \star *}$ & $0.014^{\star \star *}$ & $0.013^{\star \star *}$ & $0.014^{\star \star *}$ & $0.014^{\star \star \star}$ & $0.014^{\star \star *}$ \\
\hline & & 0.00 & 0.00 & 0.00 & 0.00 & 0.00 & 0.00 \\
\hline \multirow[t]{2}{*}{ Banking Crisis dummy } & & & $-0.021^{* *}$ & & & & \\
\hline & & & 0.01 & & & & \\
\hline \multirow[t]{2}{*}{ Log Balance Sheet } & & & & $-0.053+$ & & & \\
\hline & & & & 0.04 & & & \\
\hline \multirow[t]{2}{*}{$\Delta$ Spread US } & & & & & -0.001 & & \\
\hline & & & & & 0.01 & & \\
\hline \multirow[t]{2}{*}{$\Delta \mathrm{FX}$ Intern. Reserves } & & & & & & 0.109 & \\
\hline & & & & & & 0.12 & \\
\hline \multirow[t]{2}{*}{$\Delta$ Fin. System Deposits } & & & & & & & $0.010^{* *}$ \\
\hline & & & & & & & 0.00 \\
\hline \multirow[t]{2}{*}{ Constant } & $0.106+$ & 0.067 & 0.077 & $1.849+$ & 0.015 & 0.062 & $0.111^{* * *}$ \\
\hline & 0.07 & 0.06 & 0.08 & 1.19 & 0.08 & 0.05 & 0.04 \\
\hline Observations & 551 & 519 & 403 & 459 & 363 & 519 & 468 \\
\hline Number of countries & 18 & 18 & 17 & 18 & 13 & 18 & 18 \\
\hline
\end{tabular}

Note: This table shows panel regressions where the dependent variable is quarterly aggregate rate of growth of short-term external debt in the banking sector of country $i$ at time $t$. For each independent variable, the first row shows the coefficient and the second row the standard error. $* * * * *, *$ and + indicate significance at the $1 \%, 5 \%, 10 \%$ and $15 \%$ level, respectively. 
Table 13. The impact of currency-based measure on short-term external debt - Pre and post 2009

\begin{tabular}{|c|c|c|c|c|c|c|c|}
\hline & (1) & (2) & (3) & (4) & (5) & (6) & (7) \\
\hline VARIABLES & $\mathrm{RE}$ & $\mathrm{RE}$ & $\mathrm{RE}$ & $\mathrm{RE}$ & $\mathrm{RE}$ & $\mathrm{RE}$ & $\mathrm{RE}$ \\
\hline \multirow[t]{2}{*}{ CBCFM - Post 2009 (-1) } & $-0.018+$ & -0.015 & -0.010 & $-0.018+$ & -0.015 & $-0.018+$ & -0.016 \\
\hline & 0.01 & 0.01 & 0.02 & 0.01 & 0.01 & 0.01 & 0.02 \\
\hline \multirow[t]{2}{*}{ CBCFM - Pre 2009 (-1) } & $-0.046^{* *}$ & $-0.044^{* *}$ & $-0.045^{\star \star}$ & $-0.056^{* \star \star}$ & $-0.058^{\star * \star}$ & $-0.042^{*}$ & $-0.049^{* *}$ \\
\hline & 0.02 & 0.02 & 0.02 & 0.02 & 0.02 & 0.02 & 0.02 \\
\hline \multirow[t]{2}{*}{ fc } & $0.037^{\star \star \star}$ & $0.025^{\star}$ & & & & & \\
\hline & 0.01 & 0.01 & & & & & \\
\hline \multirow[t]{2}{*}{$\mathrm{VIX}$} & -0.030 & -0.017 & -0.015 & -0.029 & 0.002 & -0.013 & $-0.029^{\star *}$ \\
\hline & 0.02 & 0.02 & 0.03 & 0.02 & 0.03 & 0.02 & 0.01 \\
\hline \multirow[t]{2}{*}{ GDP (growth rate) } & $0.119^{\star \star \star}$ & $0.158^{\star * *}$ & $0.135^{\star \star \star}$ & $0.171^{\star \star \star}$ & 0.275 & $0.132^{* \star *}$ & $0.169^{\star \star *}$ \\
\hline & 0.03 & 0.04 & 0.03 & 0.04 & 0.23 & 0.04 & 0.04 \\
\hline \multirow[t]{2}{*}{$\Delta$ Exch. Rate } & $0.666^{\star \star *}$ & $0.775^{\star \star \star}$ & $0.687^{\star \star *}$ & $0.796^{* \star \star}$ & $0.763^{\star \star \star}$ & $0.798^{* * \star}$ & $0.802^{\star * *}$ \\
\hline & 0.12 & 0.15 & 0.12 & 0.16 & 0.11 & 0.15 & 0.15 \\
\hline \multirow[t]{2}{*}{$\begin{array}{l}\Delta \text { Bank Credit / Bank } \\
\text { Deposits }\end{array}$} & & $0.013^{\star \star \star}$ & $0.014^{* * \star}$ & $0.013^{\star \star \star}$ & $0.014^{* \star *}$ & $0.014^{\star * \star}$ & $0.014^{* * *}$ \\
\hline & & 0.00 & 0.00 & 0.00 & 0.00 & 0.00 & 0.00 \\
\hline \multirow[t]{2}{*}{ Banking Crisis dummy } & & & $-0.021^{* *}$ & & & & \\
\hline & & & 0.01 & & & & \\
\hline \multirow[t]{2}{*}{ Log Balance Sheet } & & & & $-0.054+$ & & & \\
\hline & & & & 0.03 & & & \\
\hline \multirow[t]{2}{*}{$\Delta$ Spread US } & & & & & -0.002 & & \\
\hline & & & & & 0.01 & & \\
\hline \multirow[t]{2}{*}{$\Delta \mathrm{FX}$ Intern. Reserves } & & & & & & 0.104 & \\
\hline & & & & & & 0.12 & \\
\hline \multirow[t]{2}{*}{$\Delta$ Fin. System Deposits } & & & & & & & $0.009^{* *}$ \\
\hline & & & & & & & 0.00 \\
\hline \multirow[t]{2}{*}{ Constant } & $0.107+$ & 0.068 & 0.079 & $1.887+$ & 0.018 & 0.063 & $0.111^{\star \star *}$ \\
\hline & 0.07 & 0.06 & 0.07 & 1.18 & 0.07 & 0.05 & 0.04 \\
\hline Observations & 551 & 519 & 403 & 459 & 363 & 519 & 468 \\
\hline Number of country1 & 18 & 18 & 17 & 18 & 13 & 18 & 18 \\
\hline
\end{tabular}

Note: This table shows panel regressions where the dependent variable is quarterly aggregate rate of growth of short-term external debt in the banking sector of country $i$ at time t. The policy variable (CBCFM) has been interacted two dummies for the pre- and post-2009 period, respectively. For each independent variable, the first row shows the coefficient and the second row the standard error. $* * * * * *$ and + indicate significance at the $1 \%, 5 \%, 10 \%$ and $15 \%$ level, respectively. 
Table 14. The impact of currency-based measures on long-term external debt (1)

\begin{tabular}{|c|c|c|c|c|c|c|c|}
\hline & $(1)$ & $(2)$ & (3) & (4) & $(5)$ & (6) & $(7)$ \\
\hline VARIABLES & RE & $\mathrm{RE}$ & $\mathrm{RE}$ & $\mathrm{RE}$ & $\mathrm{RE}$ & $\mathrm{RE}$ & $\mathrm{RE}$ \\
\hline \multirow[t]{2}{*}{ CBCFM $(-1)$} & -0.005 & -0.004 & -0.013 & -0.000 & 0.002 & -0.004 & -0.005 \\
\hline & 0.01 & 0.01 & 0.01 & 0.01 & 0.01 & 0.01 & 0.01 \\
\hline \multirow[t]{2}{*}{ fc } & 0.010 & 0.015 & & & & & \\
\hline & 0.01 & 0.01 & & & & & \\
\hline \multirow[t]{2}{*}{ VIX } & -0.016 & $-0.023+$ & -0.023 & $-0.035^{* *}$ & $-0.034^{\star *}$ & -0.021 & -0.011 \\
\hline & 0.02 & 0.02 & 0.02 & 0.02 & 0.02 & 0.02 & 0.01 \\
\hline \multirow[t]{2}{*}{ GDP (growth rate) } & $0.074+$ & $0.031^{* *}$ & 0.021 & $0.031^{\star *}$ & 0.118 & 0.020 & $0.041^{* * *}$ \\
\hline & 0.05 & 0.01 & 0.02 & 0.01 & 0.10 & 0.02 & 0.02 \\
\hline \multirow[t]{2}{*}{$\Delta$ Exch. Rate } & $0.422^{\star *}$ & $0.206^{\star \star *}$ & $0.162^{\star \star \star}$ & $0.200^{* * *}$ & $0.172^{\star \star}$ & $0.215^{* * *}$ & $0.237^{* * *}$ \\
\hline & 0.21 & 0.06 & 0.06 & 0.06 & 0.08 & 0.06 & 0.06 \\
\hline \multirow[t]{2}{*}{$\begin{array}{l}\Delta \text { Bank Credit / Bank } \\
\text { Deposits }\end{array}$} & & 0.002 & 0.001 & 0.002 & 0.001 & 0.002 & $0.007^{* * *}$ \\
\hline & & 0.00 & 0.00 & 0.00 & 0.00 & 0.00 & 0.00 \\
\hline \multirow[t]{2}{*}{ Banking Crisis dummy } & & & $-0.051^{* * *}$ & & & & \\
\hline & & & 0.01 & & & & \\
\hline \multirow[t]{2}{*}{ Log Balance Sheet } & & & & -0.021 & & & \\
\hline & & & & 0.04 & & & \\
\hline \multirow[t]{2}{*}{$\Delta$ Spread US } & & & & & $0.008^{*}$ & & \\
\hline & & & & & 0.00 & & \\
\hline \multirow[t]{2}{*}{$\Delta F X$ Intern. Reserves } & & & & & & 0.046 & \\
\hline & & & & & & 0.08 & \\
\hline \multirow[t]{2}{*}{$\Delta$ Fin. System Deposits } & & & & & & & $0.017^{* * *}$ \\
\hline & & & & & & & 0.00 \\
\hline \multirow[t]{2}{*}{ Constant } & 0.069 & $0.085^{\star}$ & $0.095+$ & 0.808 & $0.132^{\star *}$ & $0.084^{*}$ & 0.048 \\
\hline & 0.05 & 0.05 & 0.06 & 1.35 & 0.05 & 0.05 & 0.04 \\
\hline Observations & 555 & 523 & 407 & 462 & 363 & 523 & 472 \\
\hline Number of countries & 18 & 18 & 17 & 18 & 13 & 18 & 18 \\
\hline
\end{tabular}

Note: This table shows panel regressions where the dependent variable is quarterly aggregate rate of growth of long-term external debt in the banking sector of country $i$ at time $t$. For each independent variable, the first row shows the coefficient and the second row the standard error. $* * *, * *$ and $*$ indicate significance at the $1 \%, 5 \%$ and $10 \%$ level, respectively. 
Table 15. The impact of currency-based measures on long-term external debt (2)

\begin{tabular}{|c|c|c|c|c|c|c|c|}
\hline \multirow[b]{2}{*}{ VARIABLES } & (1) & (2) & (3) & (4) & (5) & (6) & (7) \\
\hline & $\mathrm{RE}$ & $\mathrm{RE}$ & $\mathrm{RE}$ & $\mathrm{RE}$ & $\mathrm{RE}$ & $\mathrm{RE}$ & $\mathrm{RE}$ \\
\hline \multirow[t]{2}{*}{ CBCFM (-1) } & -0.006 & -0.005 & -0.014 & -0.000 & 0.002 & -0.005 & -0.006 \\
\hline & 0.01 & 0.01 & 0.01 & 0.01 & 0.01 & 0.01 & 0.01 \\
\hline \multirow[t]{2}{*}{ CBCFM (-2) } & 0.011 & 0.012 & 0.011 & 0.003 & 0.008 & 0.011 & 0.007 \\
\hline & 0.01 & 0.01 & 0.01 & 0.01 & 0.01 & 0.01 & 0.01 \\
\hline \multirow[t]{2}{*}{ fc } & 0.010 & $0.016+$ & & & & & \\
\hline & 0.01 & 0.01 & & & & & \\
\hline \multirow[t]{2}{*}{ VIX } & -0.017 & $-0.024+$ & -0.023 & $-0.035^{\star *}$ & $-0.035^{\star *}$ & -0.022 & -0.011 \\
\hline & 0.02 & 0.01 & 0.02 & 0.02 & 0.02 & 0.02 & 0.01 \\
\hline \multirow[t]{2}{*}{ GDP (growth rate) } & $0.073+$ & $0.030^{\star *}$ & 0.020 & $0.031^{\star \star}$ & 0.109 & 0.019 & $0.040^{\star * *}$ \\
\hline & 0.05 & 0.01 & 0.02 & 0.01 & 0.11 & 0.02 & 0.02 \\
\hline \multirow[t]{2}{*}{$\Delta$ Exch. Rate } & $0.419^{\star *}$ & $0.202^{* * *}$ & $0.160^{* * *}$ & $0.199^{\star * *}$ & $0.177^{\star *}$ & $0.211^{* * *}$ & $0.235^{\star \star *}$ \\
\hline & 0.21 & 0.06 & 0.06 & 0.06 & 0.08 & 0.06 & 0.06 \\
\hline \multirow[t]{2}{*}{$\begin{array}{l}\Delta \text { Bank Credit / Bank } \\
\text { Deposits }\end{array}$} & & 0.002 & 0.001 & 0.002 & 0.001 & 0.002 & $0.007^{\star \star *}$ \\
\hline & & 0.00 & 0.00 & 0.00 & 0.00 & 0.00 & 0.00 \\
\hline \multirow[t]{2}{*}{ Banking Crisis dummy } & & & $-0.047^{* * *}$ & & & & \\
\hline & & & 0.01 & & & & \\
\hline \multirow[t]{2}{*}{ Log Balance Sheet } & & & & -0.022 & & & \\
\hline & & & & 0.04 & & & \\
\hline \multirow[t]{2}{*}{$\Delta$ Spread US } & & & & & $0.008^{*}$ & & \\
\hline & & & & & 0.00 & & \\
\hline \multirow[t]{2}{*}{$\Delta \mathrm{FX}$ Intern. Reserves } & & & & & & 0.044 & \\
\hline & & & & & & 0.08 & \\
\hline \multirow[t]{2}{*}{$\Delta$ Fin. System Deposits } & & & & & & & $0.017^{\star * *}$ \\
\hline & & & & & & & 0.00 \\
\hline \multirow[t]{2}{*}{ Constant } & 0.070 & $0.086^{*}$ & $0.096+$ & 0.837 & $0.134^{\star *}$ & $0.086^{*}$ & 0.049 \\
\hline & 0.05 & 0.05 & 0.06 & 1.36 & 0.05 & 0.05 & 0.04 \\
\hline Observations & 555 & 523 & 407 & 462 & 363 & 523 & 472 \\
\hline Number of countries & 18 & 18 & 17 & 18 & 13 & 18 & 18 \\
\hline
\end{tabular}

Note: This table shows panel regressions where the dependent variable is quarterly aggregate rate of growth of long-term external debt in the banking sector of country $i$ at time $t$. For each independent variable, the first row shows the coefficient and the second row the standard error. $* * * * *$ and $*$ indicate significance at the $1 \%, 5 \%$ and $10 \%$ level, respectively. 
Table 16. The effect of currency-based measures on short-term external debt - Robustness check

\begin{tabular}{|c|c|c|c|c|c|c|c|}
\hline & $(1)$ & (2) & (3) & (4) & (5) & (6) & (7) \\
\hline VARIABLES & $A B$ & $\mathrm{AB}$ & $A B$ & $A B$ & $A B$ & $A B$ & $A B$ \\
\hline \multirow{2}{*}{$\begin{array}{l}\text { Ext. Debt }(-1) \text { - (growth } \\
\text { rate) }\end{array}$} & $0.760^{* * *}$ & $0.761^{* * *}$ & $0.811^{* * *}$ & $0.767^{\star * *}$ & $0.694^{* * *}$ & $0.733^{* * *}$ & $0.728^{* * *}$ \\
\hline & 0.06 & 0.05 & 0.07 & 0.05 & 0.09 & 0.05 & 0.08 \\
\hline \multirow{2}{*}{ CBCFM $(-1)$} & $-0.031^{\star *}$ & $-0.032^{* *}$ & $-0.036^{*}$ & $-0.022+$ & $-0.018+$ & $-0.026^{*}$ & $-0.033^{* *}$ \\
\hline & 0.01 & 0.02 & 0.02 & 0.01 & 0.01 & 0.01 & 0.02 \\
\hline \multirow[t]{2}{*}{ fc } & -0.042 & $-0.069^{*}$ & $-0.080+$ & $-0.064+$ & $-0.072+$ & $-0.070^{*}$ & $-0.078^{\star}$ \\
\hline & 0.04 & 0.04 & 0.05 & 0.04 & 0.04 & 0.04 & 0.04 \\
\hline \multirow[t]{2}{*}{ VIX } & $1.356^{\star * *}$ & $1.219^{* * *}$ & $1.143^{* * *}$ & $1.301^{* * *}$ & $0.902^{* * *}$ & $1.008^{* * *}$ & $1.069^{\star * *}$ \\
\hline & 0.36 & 0.32 & 0.33 & 0.35 & 0.29 & 0.25 & 0.26 \\
\hline \multirow[t]{2}{*}{ GDP (growth rate) } & 0.256 & $0.255^{\star *}$ & $0.245^{*}$ & $0.250^{*}$ & $0.508^{*}$ & 0.112 & $0.238^{*}$ \\
\hline & 0.17 & 0.12 & 0.12 & 0.12 & 0.27 & 0.13 & 0.11 \\
\hline \multirow[t]{2}{*}{$\Delta$ Exch. Rate } & & $0.006^{\star *}$ & $0.007^{\star * *}$ & $0.006^{\star *}$ & $0.004^{*}$ & $0.006^{* *}$ & $0.008^{* *}$ \\
\hline & & 0.00 & 0.00 & 0.00 & 0.00 & 0.00 & 0.00 \\
\hline \multirow{2}{*}{$\begin{array}{l}\Delta \text { Bank Credit / Bank } \\
\text { Deposits }\end{array}$} & & & -0.152 & & & & \\
\hline & & & 0.13 & & & & \\
\hline \multirow[t]{2}{*}{ Banking Crisis dummy } & & & & 0.004 & & & \\
\hline & & & & 0.08 & & & \\
\hline \multirow[t]{2}{*}{ Log Balance Sheet } & & & & & 0.007 & & \\
\hline & & & & & 0.01 & & \\
\hline \multirow[t]{2}{*}{$\Delta$ Spread US } & & & & & & 0.157 & \\
\hline & & & & & & 0.14 & \\
\hline \multirow[t]{2}{*}{$\Delta \mathrm{FX}$ Intern. Reserves } & & & & & & & 0.004 \\
\hline & & & & & & & 0.01 \\
\hline Observations & 548 & 514 & 399 & 454 & 362 & 514 & 465 \\
\hline Number of countries & 18 & 18 & 17 & 18 & 13 & 18 & 18 \\
\hline F-Test & 0 & 0 & 0 & 0 & $7.14 e-11$ & 0 & 0 \\
\hline $\operatorname{AR}(1)$ & 0.00817 & 0.0100 & 0.00757 & 0.00772 & 0.0632 & 0.00865 & 0.0157 \\
\hline $\operatorname{AR}(2)$ & 0.313 & 0.324 & 0.0939 & 0.241 & 0.395 & 0.322 & 0.522 \\
\hline Sargan Test & 0.0792 & 0.301 & 0.257 & 0.165 & 0.106 & 0.204 & 0.0822 \\
\hline Hansen Test & 1 & 1 & 1 & 1 & 1 & 1 & 1 \\
\hline
\end{tabular}

Note: This table shows difference GMM panel regressions where the dependent variable is quarterly difference of the logarithm of short-term external debt in the banking sector of country $i$ at time t. For each independent variable, the first row shows the coefficient and the second row the standard error. $* * *, * *$ and $*$ indicate significance at the $1 \%, 5 \%$ and $10 \%$ level, respectively. 
Table 17. The impact of currency-based measures on external debt components - loans

\begin{tabular}{|c|c|c|c|c|c|c|c|}
\hline & (1) & (2) & (3) & (4) & (5) & (6) & (7) \\
\hline VARIABLES & RE & RE & RE & RE & RE & $\mathrm{RE}$ & $\mathrm{RE}$ \\
\hline \multirow[t]{2}{*}{ CBCFM $(-1)$} & $-0.022^{*}$ & $-0.021^{*}$ & $-0.037^{\star \star \star}$ & $-0.015+$ & $-0.021+$ & $-0.023^{\star *}$ & $-0.025^{\star}$ \\
\hline & 0.01 & 0.01 & 0.01 & 0.01 & 0.01 & 0.01 & 0.01 \\
\hline \multirow[t]{2}{*}{ fc } & $0.040^{\star * *}$ & $0.032^{\star \star}$ & & & & & \\
\hline & 0.01 & 0.02 & & & & & \\
\hline \multirow[t]{2}{*}{ VIX } & -0.018 & -0.010 & -0.009 & -0.018 & $-0.035^{\star}$ & -0.006 & 0.007 \\
\hline & 0.02 & 0.02 & 0.02 & 0.02 & 0.02 & 0.02 & 0.02 \\
\hline \multirow[t]{2}{*}{ GDP (growth rate) } & $0.067^{*}$ & $0.076^{*}$ & $0.067+$ & $0.085^{\star \star}$ & 0.015 & 0.062 & $0.092^{\star *}$ \\
\hline & 0.04 & 0.04 & 0.04 & 0.04 & 0.15 & 0.05 & 0.04 \\
\hline \multirow[t]{2}{*}{$\Delta$ Exch. Rate } & $0.403^{\star * *}$ & $0.412^{\star \star *}$ & $0.367^{\star *}$ & $0.421^{\star \star *}$ & $0.380^{\star * *}$ & $0.429^{\star * \star}$ & $0.460^{\star \star *}$ \\
\hline & 0.14 & 0.15 & 0.15 & 0.14 & 0.11 & 0.15 & 0.16 \\
\hline \multirow{3}{*}{$\begin{array}{l}\Delta \text { Bank Credit / Bank } \\
\text { Deposits }\end{array}$} & & & & & & & \\
\hline & & $0.007^{*}$ & 0.005 & $0.006+$ & $0.009^{\star *}$ & $0.007^{\star \star}$ & $0.010^{* \star *}$ \\
\hline & & 0.00 & 0.00 & 0.00 & 0.00 & 0.00 & 0.00 \\
\hline \multirow[t]{2}{*}{ Banking Crisis dummy } & & & $-0.046^{\star \star *}$ & & & & \\
\hline & & & 0.02 & & & & \\
\hline \multirow[t]{2}{*}{ Log Balance Sheet } & & & & -0.038 & & & \\
\hline & & & & 0.05 & & & \\
\hline \multirow[t]{2}{*}{$\Delta$ Spread US } & & & & & $0.006+$ & & \\
\hline & & & & & 0.00 & & \\
\hline \multirow[t]{2}{*}{$\Delta \mathrm{FX}$ Intern. Reserves } & & & & & & 0.065 & \\
\hline & & & & & & 0.08 & \\
\hline \multirow[t]{2}{*}{$\Delta$ Fin. System Deposits } & & & & & & & 0.014 \\
\hline & & & & & & & 0.01 \\
\hline \multirow[t]{2}{*}{ Constant } & 0.067 & 0.045 & 0.066 & 1.337 & $0.138^{\star *}$ & 0.047 & 0.004 \\
\hline & 0.06 & 0.06 & 0.07 & 1.55 & 0.06 & 0.05 & 0.05 \\
\hline Observations & 435 & 425 & 336 & 376 & 267 & 425 & 374 \\
\hline Number of countries & 15 & 15 & 14 & 15 & 10 & 15 & 15 \\
\hline
\end{tabular}

Note: This table shows panel regressions where the dependent variable is quarterly aggregate growth rate of short-term external loans in the banking sector of country $i$ at time $t$. For each independent variable, the first row shows the coefficient and the second row the standard error. $* * *, * *$ and $*$ indicate significance at the $1 \%, 5 \%$ and $10 \%$ level, respectively. 
Table 18. The impact of currency-based measures on external debt components - loans (robustness check)

\begin{tabular}{|c|c|c|c|c|c|c|c|}
\hline & (1) & (2) & (3) & (4) & (5) & (6) & (7) \\
\hline VARIABLES & $A B$ & $A B$ & $A B$ & $A B$ & $A B$ & $A B$ & $A B$ \\
\hline \multirow{2}{*}{$\begin{array}{l}\text { Loans }(-1) \text { - (growth } \\
\text { rate) }\end{array}$} & $0.814^{\star \star \star}$ & $0.794^{\star \star \star}$ & $0.809^{* \star *}$ & $0.789^{\star \star *}$ & $0.805^{\star \star \star}$ & $0.740^{\star * \star}$ & $0.759^{* * *}$ \\
\hline & 0.07 & 0.07 & 0.09 & 0.10 & 0.06 & 0.05 & 0.09 \\
\hline \multirow{2}{*}{ CBCFM $(-1)$} & $-0.026^{*}$ & $-0.025^{*}$ & $-0.028+$ & $-0.016+$ & -0.014 & $-0.028^{*}$ & $-0.034^{\star *}$ \\
\hline & 0.01 & 0.01 & 0.02 & 0.01 & 0.01 & 0.01 & 0.01 \\
\hline \multirow[t]{2}{*}{ fc } & -0.049 & -0.053 & -0.058 & -0.054 & $-0.086^{* *}$ & -0.043 & $-0.056^{*}$ \\
\hline & 0.03 & 0.04 & 0.05 & 0.04 & 0.03 & 0.04 & 0.03 \\
\hline \multirow[t]{2}{*}{ VIX } & $1.069^{* * *}$ & $1.021^{* * *}$ & $1.155^{\star * *}$ & $1.043^{* * *}$ & $0.875^{\star * *}$ & $0.944^{* * *}$ & $0.955^{\star * *}$ \\
\hline & 0.25 & 0.20 & 0.27 & 0.26 & 0.23 & 0.24 & 0.18 \\
\hline \multirow[t]{2}{*}{ GDP (growth rate) } & $0.251^{* *}$ & $0.306^{\star * *}$ & $0.339^{* *}$ & $0.289^{* * *}$ & $0.343^{\star *}$ & $0.218+$ & $0.309^{* \star *}$ \\
\hline & 0.09 & 0.10 & 0.12 & 0.09 & 0.13 & 0.14 & 0.10 \\
\hline \multirow[t]{2}{*}{$\Delta$ Exch. Rate } & & 0.003 & 0.001 & $0.003^{\star *}$ & $0.004^{* *}$ & 0.003 & $0.003+$ \\
\hline & & 0.00 & 0.00 & 0.00 & 0.00 & 0.00 & 0.00 \\
\hline \multirow{2}{*}{$\begin{array}{l}\Delta \text { Bank Credit / Bank } \\
\text { Deposits }\end{array}$} & & & 0.030 & & & & \\
\hline & & & 0.15 & & & & \\
\hline \multirow[t]{2}{*}{ Banking Crisis dummy } & & & & 0.002 & & & \\
\hline & & & & 0.09 & & & \\
\hline \multirow[t]{2}{*}{ Log Balance Sheet } & & & & & -0.000 & & \\
\hline & & & & & 0.00 & & \\
\hline \multirow[t]{2}{*}{$\Delta$ Spread US } & & & & & & 0.163 & \\
\hline & & & & & & 0.13 & \\
\hline \multirow[t]{2}{*}{$\Delta \mathrm{FX}$ Intern. Reserves } & & & & & & & 0.006 \\
\hline & & & & & & & 0.01 \\
\hline Observations & 432 & 421 & 333 & 373 & 267 & 421 & 372 \\
\hline Number of countries & 15 & 15 & 14 & 15 & 10 & 15 & 15 \\
\hline F-Test & 0 & 0 & 0 & 0 & $2.86 \mathrm{e}-10$ & $7.78 \mathrm{e}-09$ & 0 \\
\hline $\mathrm{AR}(1)$ & 0.0209 & 0.0206 & 0.0238 & 0.0121 & 0.0814 & 0.0250 & 0.0216 \\
\hline $\operatorname{AR}(2)$ & 0.218 & 0.239 & 0.224 & 0.968 & 0.794 & 0.233 & 0.235 \\
\hline Sargan Test & 0.716 & 0.753 & 0.720 & 0.413 & 0.641 & 0.291 & 0.722 \\
\hline Hansen Test & 1 & 1 & 1 & 1 & 1 & 1 & 1 \\
\hline
\end{tabular}

Note: This table shows difference GMM panel regressions where the dependent variable is quarterly difference of the logarithm of short-term external debt in the banking sector of country $i$ at time $t$. For each independent variable, the first row shows the coefficient and the second row the standard error. $* * *, * *$ and * indicate significance at the $1 \%, 5 \%$ and $10 \%$ level, respectively. 
Table 19. The impact of currency-based measures on external debt components - securities

\begin{tabular}{|c|c|c|c|c|c|c|c|}
\hline VARIABLES & $\begin{array}{l}\text { (1) } \\
\mathrm{RE}\end{array}$ & $\begin{array}{l}\text { (2) } \\
\mathrm{RE}\end{array}$ & $\begin{array}{l}\text { (3) } \\
\mathrm{RE}\end{array}$ & $\begin{array}{l}\text { (4) } \\
\mathrm{RF}\end{array}$ & $\begin{array}{l}\text { (5) } \\
\mathrm{RF}\end{array}$ & $\begin{array}{l}\text { (6) } \\
\mathrm{RF}\end{array}$ & $\begin{array}{l}\text { (7) } \\
\mathrm{RF}\end{array}$ \\
\hline \multirow[t]{2}{*}{ CBCFM $(-1)$} & -0.038 & -0.037 & -0.014 & -0.039 & -0.011 & -0.038 & -0.045 \\
\hline & 0.04 & 0.04 & 0.03 & 0.04 & 0.02 & 0.04 & 0.04 \\
\hline \multirow[t]{2}{*}{ fc } & 0.008 & 0.001 & & & & & \\
\hline & 0.03 & 0.02 & & & & & \\
\hline \multirow[t]{2}{*}{ VIX } & -0.025 & -0.026 & -0.027 & -0.029 & 0.018 & -0.027 & -0.031 \\
\hline & 0.03 & 0.03 & 0.02 & 0.03 & 0.03 & 0.02 & 0.03 \\
\hline \multirow[t]{2}{*}{ GDP (growth rate) } & 0.183 & 0.149 & 0.171 & 0.157 & 0.586 & 0.158 & 0.154 \\
\hline & 0.13 & 0.13 & 0.15 & 0.13 & 0.43 & 0.15 & 0.14 \\
\hline \multirow[t]{2}{*}{$\Delta$ Exch. Rate } & $0.807^{*}$ & 0.627 & 0.705 & 0.666 & $0.927^{* *}$ & 0.619 & 0.637 \\
\hline & 0.48 & 0.49 & 0.57 & 0.47 & 0.47 & 0.48 & 0.51 \\
\hline \multirow{3}{*}{$\begin{array}{l}\Delta \text { Bank Credit / Bank } \\
\text { Deposits }\end{array}$} & & & & & & & \\
\hline & & 0.005 & $0.006+$ & 0.006 & 0.002 & 0.005 & $0.007+$ \\
\hline & & 0.00 & 0.00 & 0.01 & 0.00 & 0.00 & 0.00 \\
\hline \multirow[t]{2}{*}{ Banking Crisis dummy } & & & 0.012 & & & & \\
\hline & & & 0.09 & & & & \\
\hline \multirow[t]{2}{*}{ Log Balance Sheet } & & & & 0.085 & & & \\
\hline & & & & 0.06 & & & \\
\hline \multirow[t]{2}{*}{$\Delta$ Spread US } & & & & & $-0.026^{*}$ & & \\
\hline & & & & & 0.02 & & \\
\hline \multirow[t]{2}{*}{$\Delta \mathrm{FX}$ Intern. Reserves } & & & & & & -0.032 & \\
\hline & & & & & & 0.10 & \\
\hline \multirow[t]{2}{*}{$\Delta$ Fin. System Deposits } & & & & & & & 0.006 \\
\hline & & & & & & & 0.01 \\
\hline \multirow[t]{2}{*}{ Constant } & 0.103 & $0.109+$ & $0.096+$ & -2.637 & -0.012 & $0.111+$ & $0.122+$ \\
\hline & 0.08 & 0.07 & 0.06 & 2.13 & 0.08 & 0.07 & 0.08 \\
\hline Observations & 475 & 443 & 336 & 395 & 302 & 443 & 392 \\
\hline Number of countries & 16 & 16 & 15 & 16 & 12 & 16 & 16 \\
\hline
\end{tabular}

Note: This table shows panel regressions where the dependent variable is quarterly aggregate rate of growth of short-term external securities in the banking sector of country $i$ at time $t$. For each independent variable, the first row shows the coefficient and the second row the standard error. $* * *, * *$ and $*$ indicate significance at the $1 \%, 5 \%$ and $10 \%$ level, respectively. 
Table 20. The impact of currency-based measures on external debt components - deposits

\begin{tabular}{|c|c|c|c|c|c|c|c|}
\hline & (1) & $(2)$ & (3) & (4) & (5) & (6) & (7) \\
\hline VARIABLES & RE & $\mathrm{RE}$ & RE & $\mathrm{RE}$ & $\mathrm{RE}$ & $\mathrm{RE}$ & $\mathrm{RE}$ \\
\hline \multirow[t]{2}{*}{ CBCFM (-1) } & 0.001 & 0.000 & 0.002 & 0.003 & 0.012 & 0.000 & -0.006 \\
\hline & 0.01 & 0.01 & 0.01 & 0.01 & 0.01 & 0.01 & 0.01 \\
\hline \multirow[t]{2}{*}{ fc } & 0.015 & 0.006 & & & & & \\
\hline & 0.02 & 0.01 & & & & & \\
\hline \multirow[t]{2}{*}{ VIX } & $-0.034^{* *}$ & $-0.032^{* *}$ & $-0.032^{* *}$ & -0.016 & -0.019 & $-0.030^{* *}$ & $-0.033^{* *}$ \\
\hline & 0.01 & 0.01 & 0.02 & 0.02 & 0.02 & 0.01 & 0.01 \\
\hline \multirow[t]{2}{*}{ GDP (growth rate) } & $0.106^{\star *}$ & $0.113^{* *}$ & $0.117^{\star *}$ & $0.139^{* * *}$ & -0.042 & $0.100^{*}$ & $0.102^{* *}$ \\
\hline & 0.04 & 0.04 & 0.05 & 0.05 & 0.28 & 0.06 & 0.04 \\
\hline \multirow[t]{2}{*}{$\Delta$ Exch. Rate } & $0.475^{\star *}$ & $0.485^{\star *}$ & $0.505^{\star}$ & $0.586^{\star *}$ & $0.666^{*}$ & $0.497^{\star *}$ & $0.435^{\star *}$ \\
\hline & 0.20 & 0.22 & 0.26 & 0.24 & 0.35 & 0.21 & 0.22 \\
\hline \multirow{3}{*}{$\begin{array}{l}\Delta \text { Bank Credit / Bank } \\
\text { Deposits }\end{array}$} & & & & & & & \\
\hline & & 0.005 & $0.006+$ & 0.004 & 0.000 & 0.005 & $0.010^{\star *}$ \\
\hline & & 0.00 & 0.00 & 0.00 & 0.00 & 0.00 & 0.00 \\
\hline \multirow[t]{2}{*}{ Banking Crisis dummy } & & & $-0.032^{\star *}$ & & & & \\
\hline & & & 0.01 & & & & \\
\hline \multirow{2}{*}{ Log Balance Sheet } & & & & -0.009 & & & \\
\hline & & & & 0.05 & & & \\
\hline \multirow[t]{2}{*}{$\Delta$ Spread US } & & & & & $-0.021+$ & & \\
\hline & & & & & 0.01 & & \\
\hline \multirow[t]{2}{*}{$\Delta \mathrm{FX}$ Intern. Reserves } & & & & & & 0.052 & \\
\hline & & & & & & 0.10 & \\
\hline \multirow[t]{2}{*}{$\Delta$ Fin. System Deposits } & & & & & & & $0.009^{* *}$ \\
\hline & & & & & & & 0.00 \\
\hline \multirow[t]{2}{*}{ Constant } & $0.132^{\star * *}$ & $0.129^{\star * \star}$ & $0.135^{\star \star \star}$ & 0.369 & $0.093+$ & $0.127^{\star \star \star}$ & $0.129^{\star * \star}$ \\
\hline & 0.04 & 0.04 & 0.05 & 1.75 & 0.06 & 0.04 & 0.05 \\
\hline Observations & 502 & 482 & 379 & 425 & 328 & 482 & 431 \\
\hline Number of countries & 17 & 17 & 16 & 17 & 12 & 17 & 17 \\
\hline
\end{tabular}

Note: This table shows panel regressions where the dependent variable is quarterly aggregate rate of growth of short-term external deposits in the banking sector of country $i$ at time t. For each independent variable, the first row shows the coefficient and the second row the standard error. $* * *, * *$ and $*$ indicate significance at the $1 \%, 5 \%$ and $10 \%$ level, respectively. 


\section{ANNEX 6 - DESCRIPTIVE TRENDS}

Figure 9. Ratio of short-term banking debt over total banking debt

(1) Australia




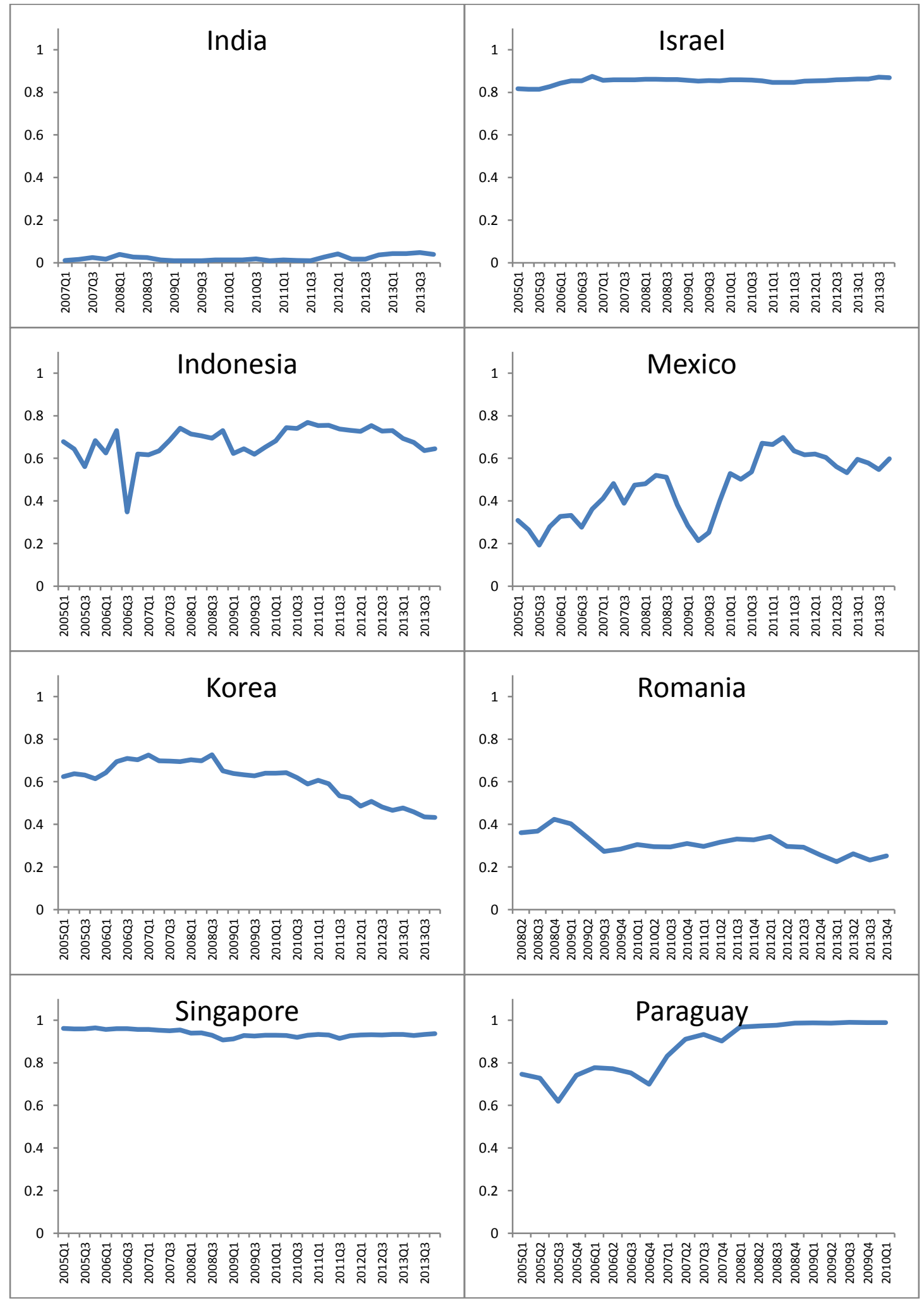




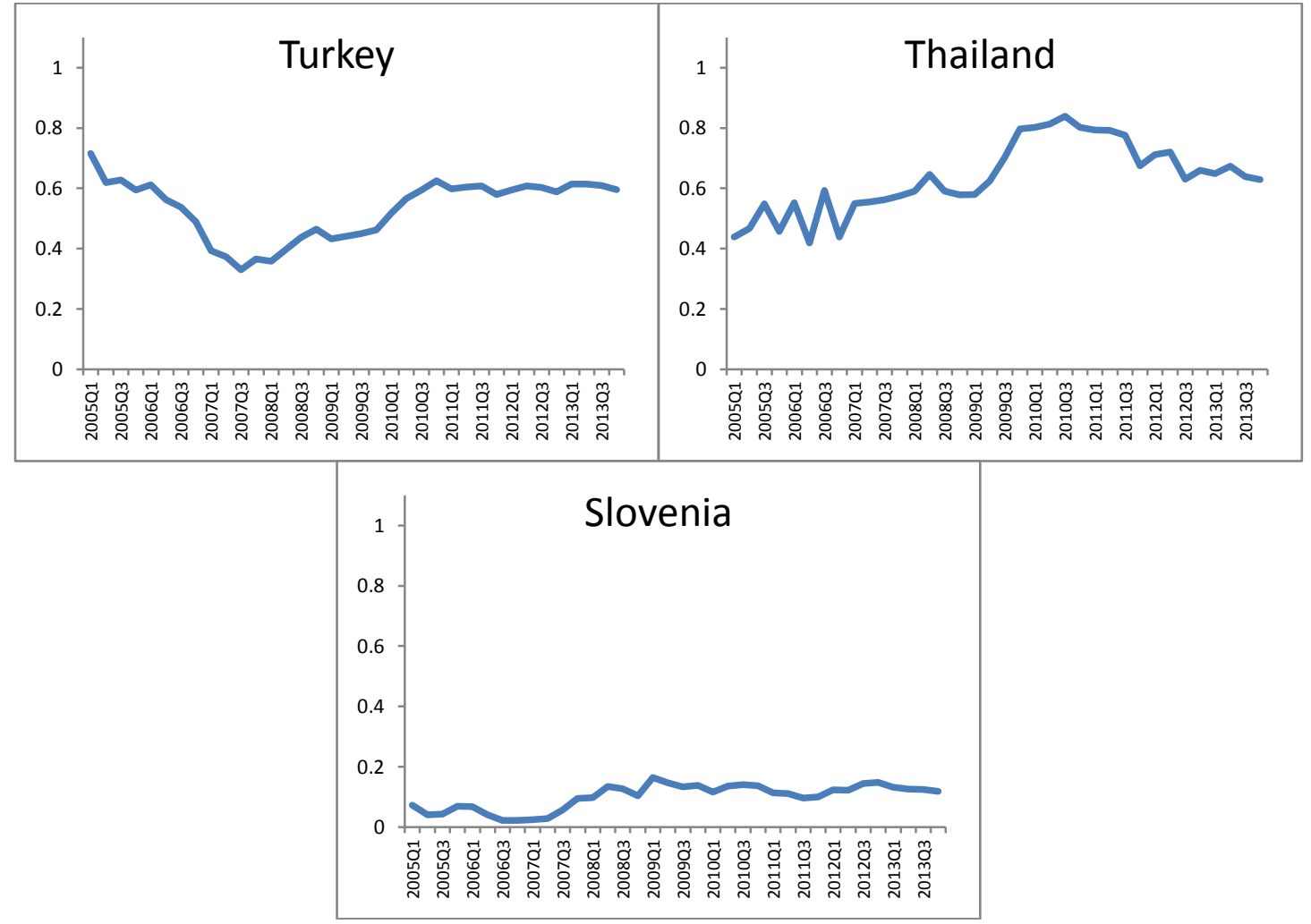

Source: OECD staff calculation (2016), from QEDS database. 
Figure 10. Rate of growth of total external banking debt

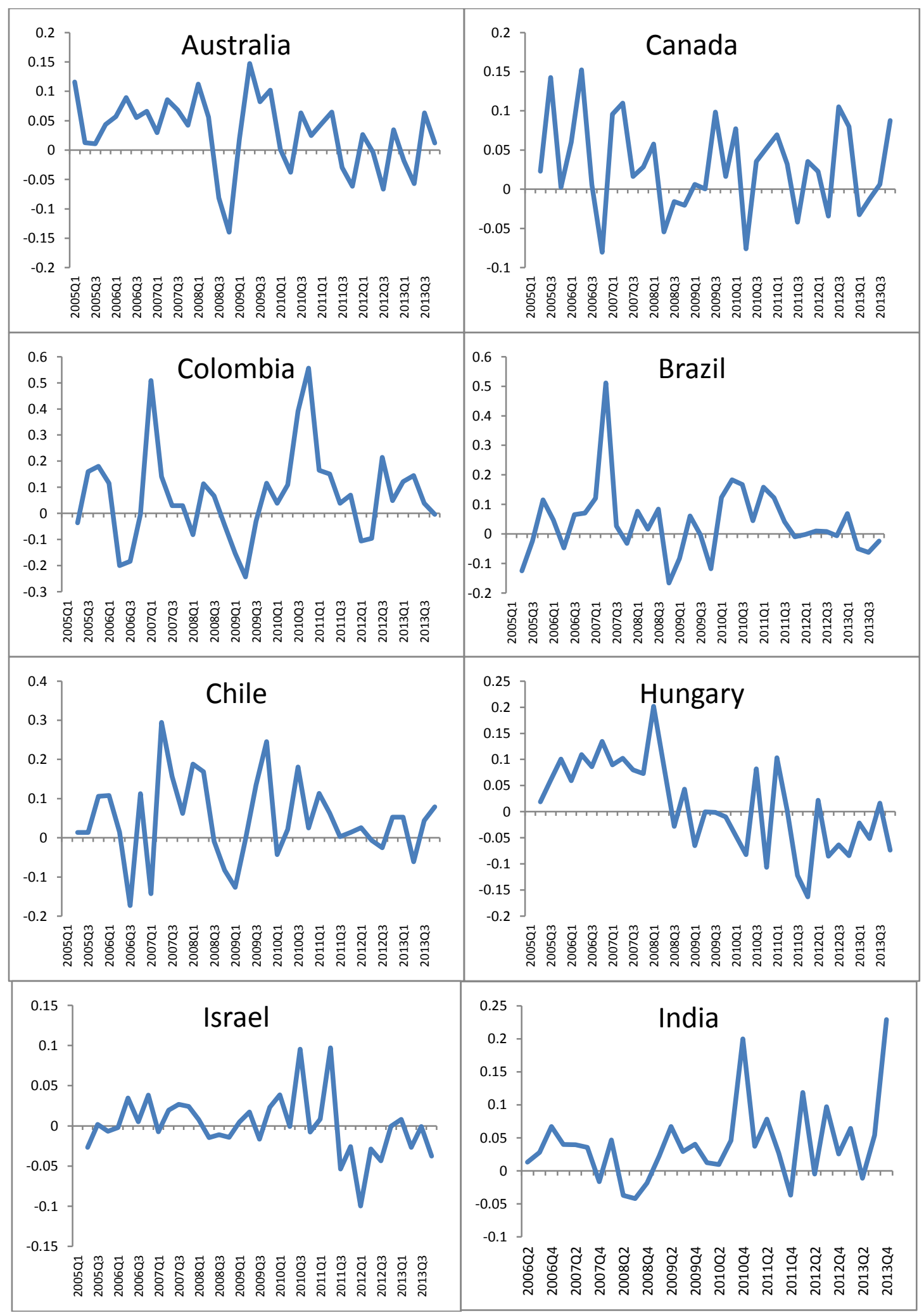




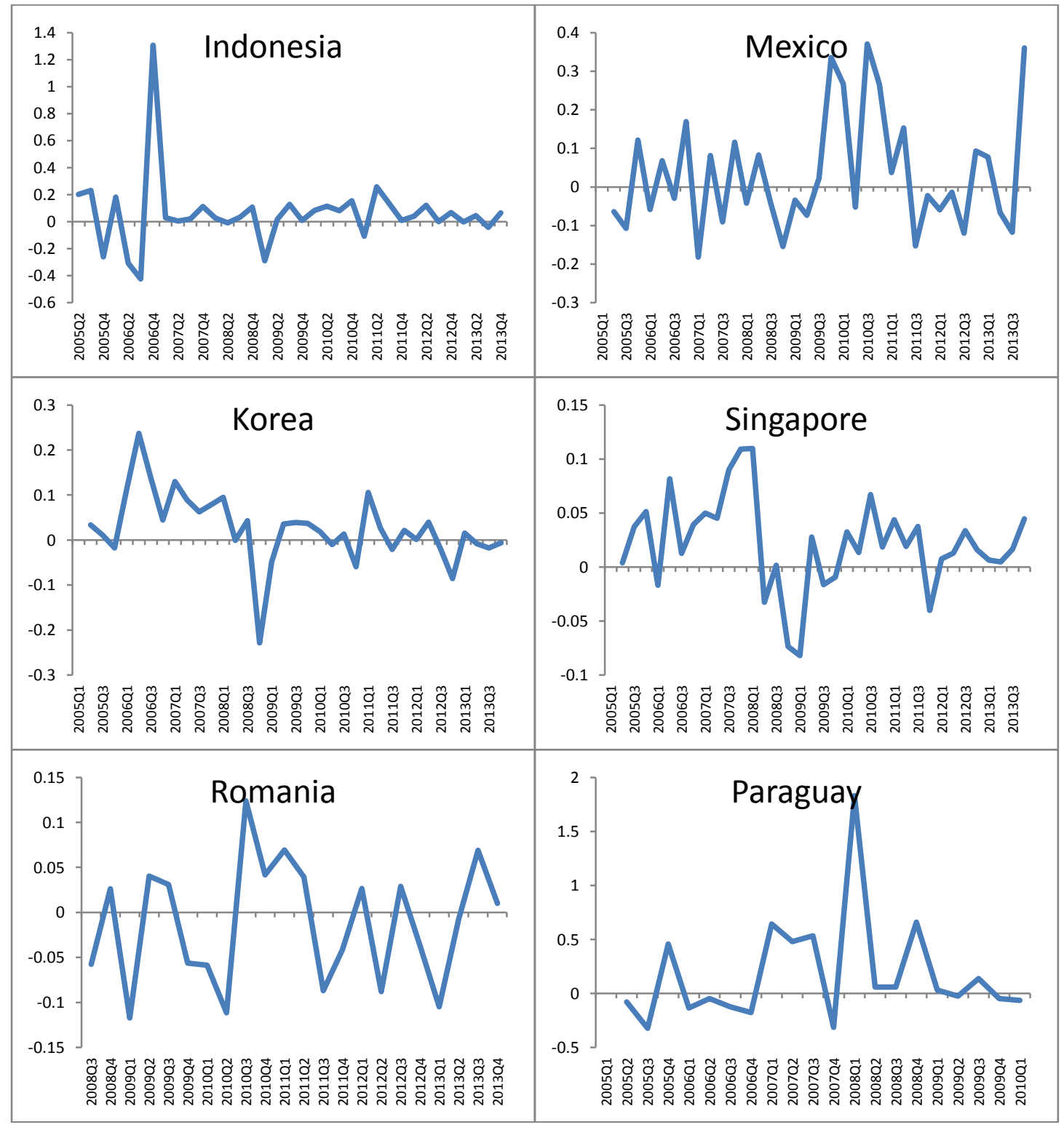



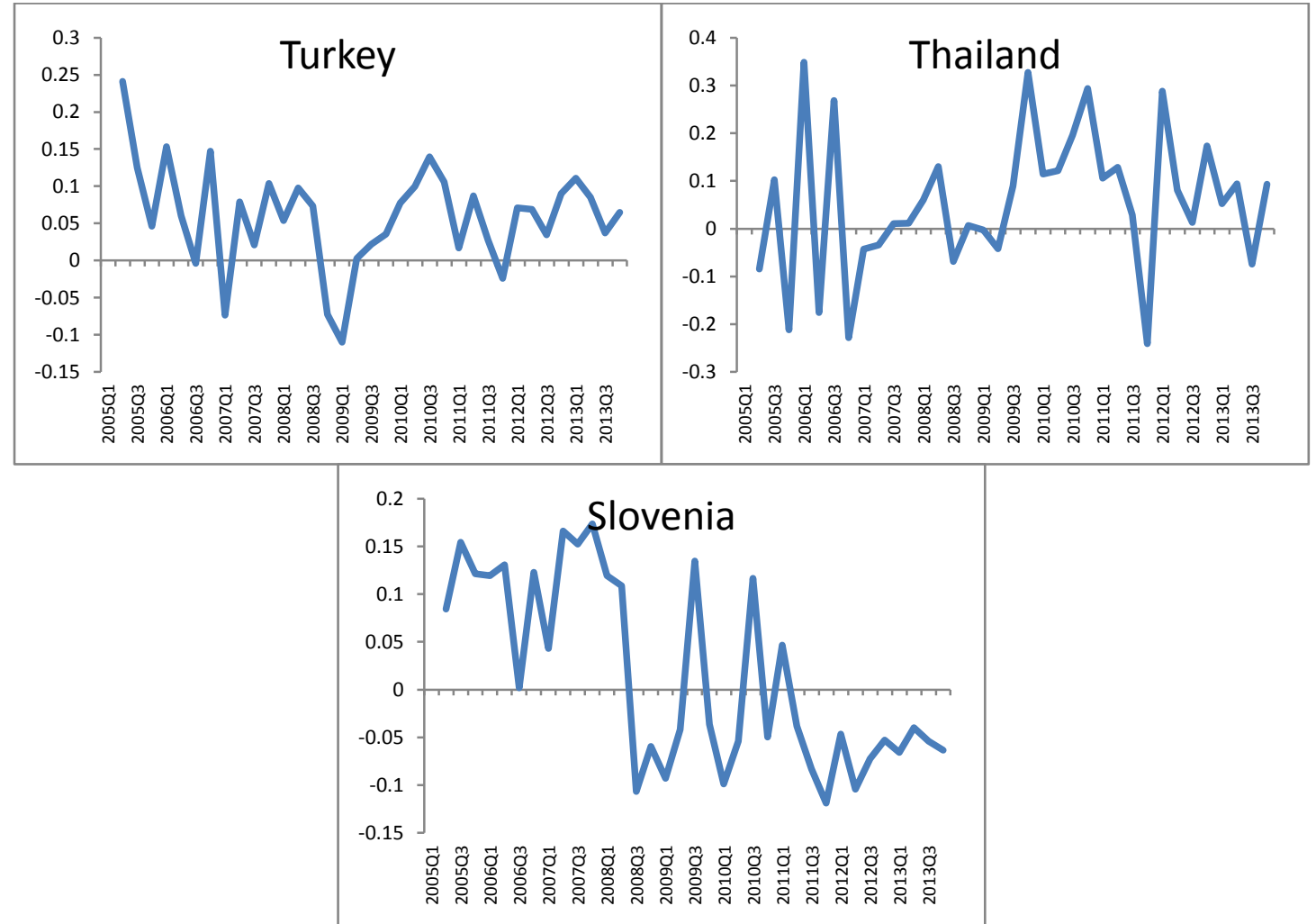

Source: OECD staff calculation (2016), from QEDS database. 


\title{
OECD Working Papers on International Investment
}

\author{
www.oecd.org/investment/working-papers.htm
}

2017/3 Addressing the balance of interests in investment treaties: The limitation of fair and equitable treatment provisions to the minimum standard of treatment under customary international law

The balance between investor protection and the right to regulate in investment treaties: A scoping paper

Foreign direct investment, corruption and the OECD Anti-Bribery Convention

State-to-State dispute settlement and the interpretation of investment treaties

Investment policies related to national security

The legal framework applicable to joint interpretive agreements of investment treaties

Currency-based measures targeting banks - Balancing national regulation of risk and financial openness

$2015 / 2$

Investment Treaties over Time - Treaty Practice and Interpretation in a Changing World

$2015 / 1$

The Policy Landscape for International Investment by Government-controlled Investors: A Fact Finding Survey

2014

$2014 / 3$

Investment Treaties and Shareholder Claims: Analysis of Treaty Practice

$2014 / 2$

Investment Treaties and Shareholder Claims for Reflective Loss: Insights from Advanced Systems of Corporate Law

Investment Treaty Law, Sustainable Development and Responsible Business Conduct: A Fact Finding Survey

Temporal validity of international investment agreements: a large sample survey of treaty provisions

China Investment Policy: an Update

Investor-state dispute settlement: A scoping paper for the investment policy community

Defining and measuring green FDI: An exploratory review of existing work and evidence

Environmental concerns in international investment agreements: a survey

OECD's FDI Restrictiveness Index: 2010 Update

$2010 / 2$

Foreign state immunity and foreign government controlled investors

2010/1

Intellectual property rights in international investment agreements

OECD's FDI regulatory restrictiveness index: Revision and extension to more economies

Interpretation of the Umbrella Clause in Investment Agreements

Investor-State Dispute Settlement in Infrastructure Projects

2006/1

Improving the System of Investor-State Dispute Settlement: An Overview 
2005/3 Corporate Responsibility Practices of Emerging Market Companies - A Fact-Finding Study

2005/2 Multilateral Influences on the OECD Guidelines for Multinational Enterprises

2005/1 Transparency and Third Party Participation in Investor-State Dispute Settlement Procedures

2004

$2004 / 6$

$2004 / 5$

2004/4

2004/3

$2004 / 2$

2004/1

2003

2003/2

2003/1

2002

$2002 / 2$

2002/1

2001

2001/6

$2001 / 5$

$2001 / 4$

2001/3

$2001 / 2$

2001/1

2000

2000/5

2000/4

2000/3

$2000 / 2$

2000/1

1999

1999/3

1999/2

1999/1

1998

Mobilising Investment for Development: Role of ODA - The 1993-2003 Experience in Vietnam

ODA and Investment for Development: What Guidance can be drawn from Investment Climate Scoreboards?

Indirect Expropriation and the Right to Regulate in International Investment Law

Fair and Equitable Treatment Standard in International Investment Law

Most-Favoured-Nation Treatment in International Investment Law

Relationships between International Investment Agreements

Business Approaches to Combating Corrupt Practices

Incentives-based Competition for Foreign Direct Investment: The Case of Brazil

Managing Working Conditions in the Supply Chain: A Fact-Finding Study of Corporate Practices

Multinational Enterprises in Situations of Violent Conflict and Widespread Human Rights Abuses

Codes of Corporate Conduct: Expanded review of their contents

The OECD Guidelines for Multinational Enterprises and other corporate responsibility instruments

Public policy and voluntary initiatives: What roles have governments played?

Making codes of corporate conduct work: Management control systems and corporate responsibility

Corporate Responsibility: Results of a fact-finding mission on private initiatives

Private Initiatives for Corporate Responsibility: An Analysis

Recent trends, policies and challenges in South East European countries

Main determinants and impacts of FDI on China's economy

Lithuania: Foreign Direct Investment Impact and Policy Analysis

Investment Patterns in a Longer-Term Perspective

Bribery and the business sector: Managing the relationship

Rules for the Global Economy: Synergies between Voluntary and Binding Approaches

Deciphering Codes of Corporate Conduct: A Review of their Contents

Southeast Asia: the Role of FDI Policies in Development

1998/1 Survey of OECD work on international investment 